\title{
Permafrost changes and engineering stability in Qinghai-Xizang Plateau
}

\author{
WU QingBai* \& NIU FuJun \\ State Key Laboratory of Frozen Soil Engineering, Cold and Arid Regions Environmental and Engineering Research Institute, Chinese Academy of \\ Sciences, Lanzhou 730000, China
}

Received June 4, 2012; accepted October 31, 2012; published online December 13, 2012

\begin{abstract}
Climate change and engineering activities are the leading causes of permafrost temperature increase, active layer thickening, and ground-ice thaw, which trigger changes in the engineering stability of embankments. Based on the important research advances on permafrost changes and frozen soil engineering in Qinghai-Xizang Plateau, the changes in permafrost temperature and active layer thickness, their relationships with climate factors, the response process of engineering activities on permafrost, dynamic change of engineering stability of Qinghai-Xizang Railway, and the cooling mechanism and process of crushed-rock layers are discussed using the monitoring data of permafrost and embankment deformation. Finally, solutions to the key scientific problems of frozen soil engineering under climate change are proposed.
\end{abstract}

climate change, engineering activity, permafrost temperature, active layer thickness, engineering stability

Citation: $\quad$ Wu Q B, Niu F J. Permafrost changes and engineering stability in Qinghai-Xizang Plateau. Chin Sci Bull, 2013, 58: 1079-1094, doi: 10.1007/s11434$012-5587-\mathrm{z}$

Frozen soil, one of the cryosphere factors most widely distributed in the Northern Hemisphere, occupies approximately $56 \%$ of the Northern Hemisphere landmass while the areal extent of permafrost covers approximately $24 \%$ of the land area [1]. Permafrost has an extensive response and feedback to climate changes [2,3]. Permafrost changes can have a large impact on land surface energy and moisture balance, and hence, on weather and climate, surface and subsurface hydrology, carbon exchange between land and atmosphere, ecosystems in cold regions, and landscape and geomorphological processes. Ground surface subsidence caused by permafrost thaw increases the risks of thermal hazards and disrupts the infrastructure stability and operations in cold regions [4,5]. Permafrost regions occupy approximately $53 \%$ of the land area in Qinghai-Xizang Plateau (QXP), which is the high-elevation permafrost most widely distributed on Earth [6,7]. Permafrost temperature increase, increase of active layer thickness (ALT), and permafrost degradation have a considerable influence on

*Corresponding author (email: qbwu@1zb.ac.cn) weather and climate, subsurface hydrology, as well as ecological environment and engineering in cold regions [8-11].

Embankments constructed in permafrost inevitably disrupt the surface energy balance, resulting in the rise of permafrost temperature and permafrost table $[12,13]$. However, the engineering stability of permafrost not only influences the thermal disturbance from engineering, but also the long-term thermal effect on climate changes. Specifically, high ice content and warm permafrost with high ice content, which has a mean annual ground temperature higher than $-1^{\circ} \mathrm{C}$ and a volume ice content more than $25 \%$, are more sensitive to climate change and engineering influence [14-16]. Climate change and engineering activities have an overlapping and complicated influence on warm permafrost, which measures such as passively protecting permafrost using only traditional rising embankment heights to increase thermal resistance cannot effectively resolve; thus, measures that can actively protect permafrost and maintain the long-term stability of embankments are needed $[14,17,18]$. Therefore, permafrost change and engineering stability under the effect of climate changes and engineering 
thermal disturbance are the key topics as well as difficulty of permafrost engineering.

\section{Permafrost change}

Permafrost change is a sensitive indicator of climate change [3]. Numerous observation sites were set up to monitor the change of the permafrost regime and ALT in the Northern Hemisphere, as well as to show the temporal and spatial changes in the pattern of the permafrost regime and ALT [19-23]. In China, studies on permafrost change in QXP started in the 1990s; these studies showed the changes in permafrost temperatures and permafrost degradation features $[24,25]$ and the effect of climate change on permafrost [26-28]. Along with the deepening of climate change and cryosphere research, some monitoring sites for permafrost temperature were built along Qinghai-Xizang Highway (QXH) in 1995 and 1998 [29,30]. These monitoring sites cross the permafrost regions $550 \mathrm{~km}$ long along QXH, including predominantly continuous permafrost regions, discontinuous permafrost regions, and island permafrost regions. Recognizing the importance of QXP permafrost to global changes, King et al. [31] proposed the conceptual monitoring network to study the change in permafrost and ALT in QXP. Eight sites were built to monitor the change in soil moisture and temperature in seasonally frozen soil and permafrost regions in QXP for the Global Energy and Water Cycle Experiment Asian Monsoon Experiment/Tibet project [32-34]. The monitoring results show that the cryosphere in China is experiencing predominant changes [35] and permafrost degradation, which lead to environmental problems $[9,36]$. Permafrost degradation and spatial as well as temporal change in permafrost temperature and ALT under the scenario of climate change have a predominant trend and result in thermal hazards [37-41]. The lower limit's northern boundary of permafrost distribution is seriously degraded in QXP [42] and the permafrost thickness greatly decreased $[43,44]$. Moreover, the seasonal freezing depth in QXP shows predominant temporal and spatial changes [45]. From 1991-2010, ALT increased about $35 \mathrm{~cm}$ and permafrost temperatures rose about 0.4 to $0.9^{\circ} \mathrm{C}$ in the headwaters of Urumqi River in Tianshan Mountains [22,46]. In the last 30 years, permafrost in the Xinganling regions showed predominant regional degradation, ALT increased by $20-40 \mathrm{~cm}$, and mean annual ground temperature rose about 0.1 to $0.2^{\circ} \mathrm{C}[47,48]$. These studies greatly promote the research of permafrost change in China.

Based on the data of monitoring sites along QXH (Figure 1), we analyzed the response of ALT and permafrost temperature to climate change in QXP. Under the effect of climate change, the freezing and thawing process within the active layer shows predominant change. The thaw duration of soils at $50 \mathrm{~cm}$ depth varied from April 25 to May 11, from 172 to $185 \mathrm{~d}$ with a mean thaw duration of about 179.5 d. The completely linked time of freezing and thawing occurred from February 11 to March 15. ALT changes in permafrost regions along QXH ranged from 132 to $457 \mathrm{~cm}$, with a spatial and temporal average of $241 \mathrm{~cm}$ [49]. ALT varied from 105 to $322 \mathrm{~cm}$ based on other monitoring sites in QXP [22]. Under the effect of climate change, ALT along QXH continuously increased from 1995 to 2010, with an average increase of $67 \mathrm{~cm}$. The annual increasing rate of ALT varied from 2.1 to $16.6 \mathrm{~cm} \mathrm{a}^{-1}$, with an average of 7.5 $\mathrm{cm} \mathrm{a}^{-1}$ (Figure 2) [49]. The mean annual increasing rate of ALT in other monitoring sites was about $4 \mathrm{~cm} \mathrm{a}^{-1}$ [22]. All the monitoring results in QXP show that ALT has great spatial and temporal difference. The mean annual increasing rate of ALT is about $5 \mathrm{~cm} \mathrm{a}^{-1}$ at cold permafrost areas in high-middle mountains, where the mean annual ground temperature is lower than $-1.5^{\circ} \mathrm{C}$, and about $11.2 \mathrm{~cm} \mathrm{a}^{-1}$ at warm permafrost areas in valleys and high plains, where the mean annual ground temperature is higher than $-1.5^{\circ} \mathrm{C}$ [49].

During the past decades, permafrost temperatures have largely risen. From 1970 to 1990 , the mean annual ground temperature of seasonally frozen soil and island permafrost rose 0.3 to $0.5^{\circ} \mathrm{C}$, and that of predominant continuous permafrost from 0.1 to $0.3^{\circ} \mathrm{C}[9,26,27]$. From 1996 to 2001, permafrost temperature near the permafrost table rose about 0.1 to $0.7^{\circ} \mathrm{C}$ [29]. For the past decade, the permafrost has

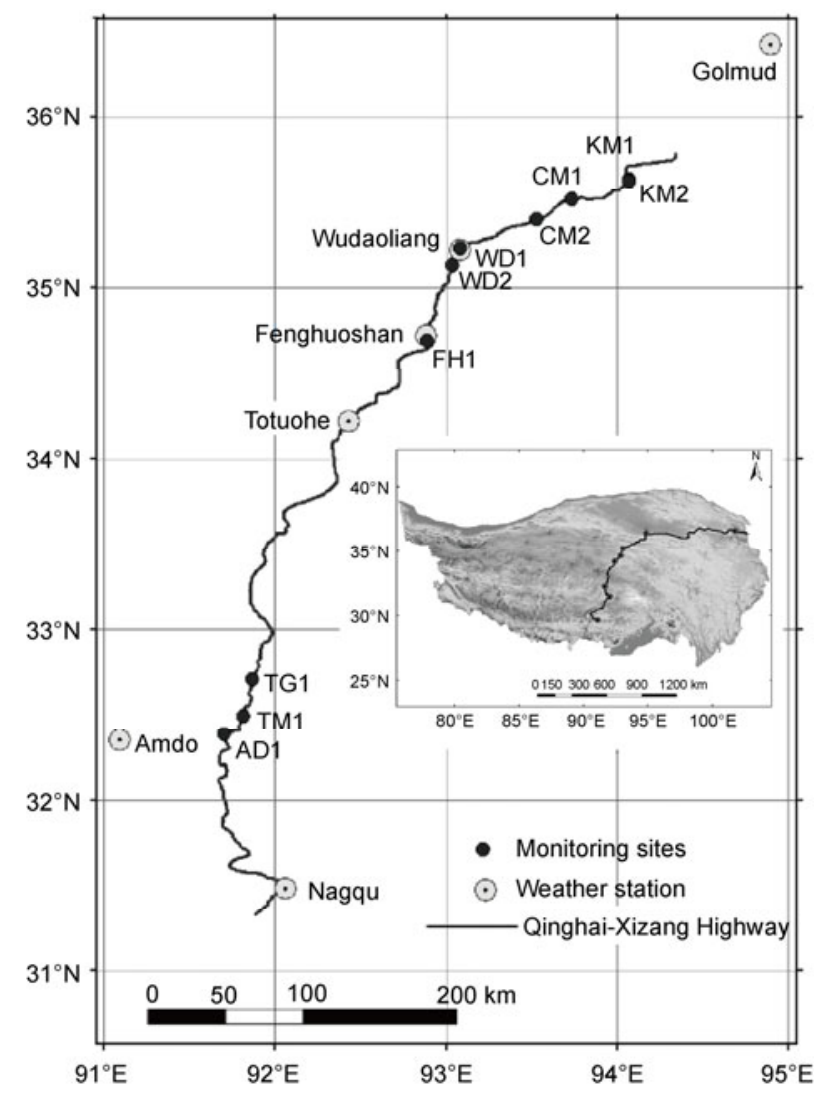

Figure 1 Monitoring sites of permafrost temperatures and ALT along QXH. 


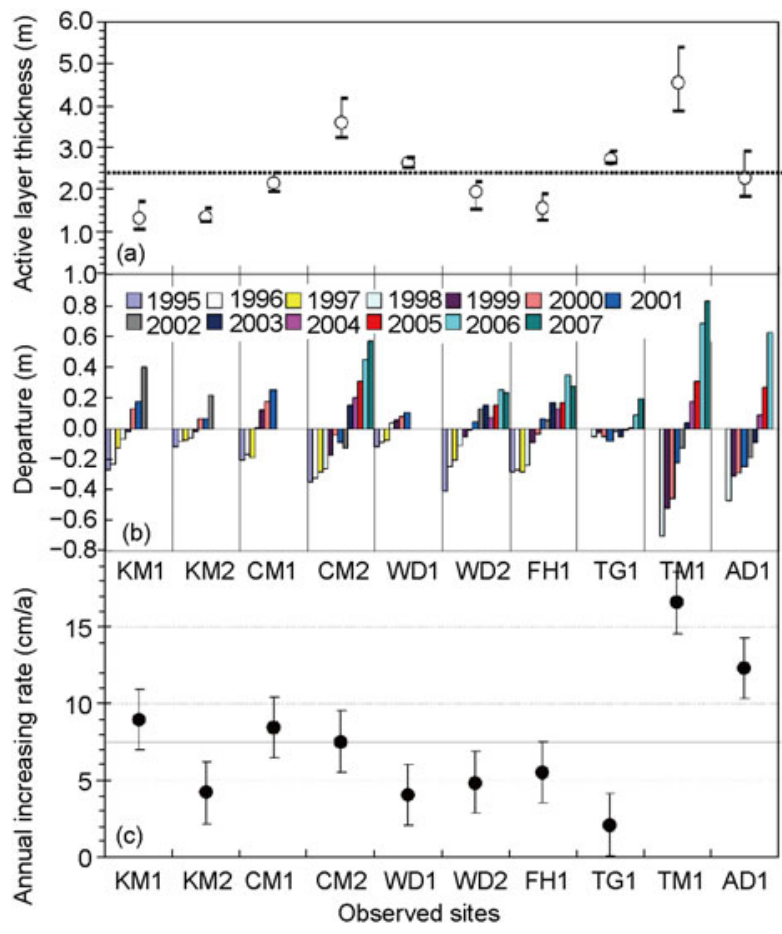

Figure 2 Active layer thickness (a), departure of active layer thickness (b), and annual increasing rate of active layer thickness (c).

shown a more predominant trend of temperature increase; the rising rate of permafrost temperature near the permafrost table is about $0.06^{\circ} \mathrm{C} \mathrm{a}^{-1}$ [22], the mean annual temperature of permafrost at $6 \mathrm{~m}$ depth has risen from 0.12 to $0.67^{\circ} \mathrm{C}$, and the rising rate of permafrost temperature at $6 \mathrm{~m}$ depth varies from 0.01 to $0.06^{\circ} \mathrm{C} \mathrm{a}^{-1}$ at an average of $0.04^{\circ} \mathrm{C} \mathrm{a}^{-1}$ (Figure 3) [10]. Permafrost temperatures show a predominant spatial and temporal difference in QXP. For cold permafrost in high-middle mountains, the rising rate of permafrost is about $0.055^{\circ} \mathrm{C} \mathrm{a}^{-1}$. For warm permafrost in high plains and valleys, the rising rate of permafrost is about $0.023^{\circ} \mathrm{C} \mathrm{a}^{-1}$. The process of permafrost phase change mainly affects the response of permafrost to climate change.

The changes in ALT and permafrost temperature in QXP are clearly larger than those in other permafrost regions, and the response of permafrost and ALT to climate change has a predominantly regional difference, showing the trend of opposite spatial and temporal change. This finding implies that local factors have an important role in ALT and permafrost changes, which, in turn, have a significant response to climate change. However, climate factors such as air temperature and precipitation control permafrost change. The statistical relationship between ALT change and subsurface soil temperature in summer shows that ALT change is closely related with the increase in mean soil temperature (July-August), but not predominant with the change of mean soil temperature in winter (December-February) $[49,50]$. For the past decade, the mean annual air temperature from four weather stations along QXH (i.e. Wudaoliang, Fenghuoshan, Tuotuohe, and Amdo) showed an increase of

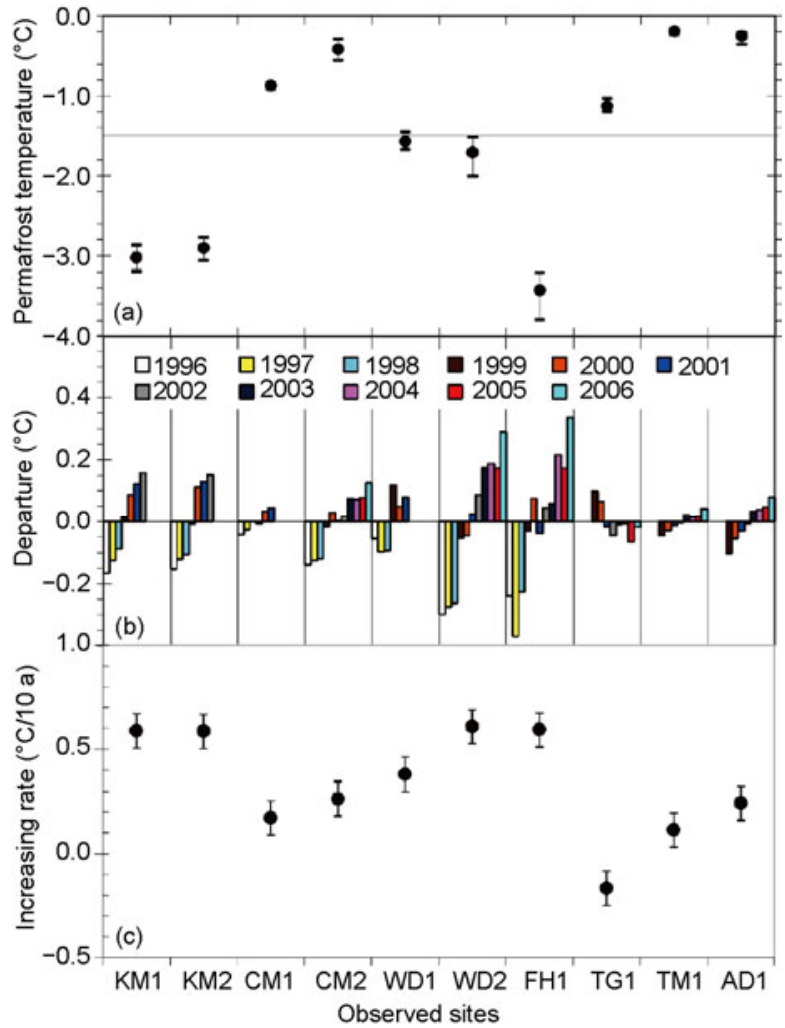

Figure 3 (a) Permafrost temperature at $6 \mathrm{~m}$ depth; (b) permafrost temperature departure; (c) annual increasing rate of permafrost temperature.

about 0.6 to $1.6^{\circ} \mathrm{C}$, which is generally sufficient to account for the permafrost warming. However, an increase in summer rainfall and a decrease in winter snowfall may be cooling factors to the underlying soil, offsetting to a lesser degree the permafrost warming. From 1995 to 2005, the permafrost temperature at a depth of $6 \mathrm{~m}$ increased year-round, with most of the increase occurring in spring and summer, but the air temperature in winter increased an average of 2.9 to $4.2^{\circ} \mathrm{C}$. Taking into consideration the significant spring and summer permafrost warming at $6 \mathrm{~m}$ depth because of the three to six months' time lag, permafrost temperature increases mainly due to increasing air temperature during winter [10].

\section{Response process of permafrost to engineer- ing activities}

Infrastructure construction on permafrost changes the radiation energy structure and energy balance of the ground surface due to changes in physical properties of the ground surface. These variations, in turn, lead to changes in the freezing and thawing process of soil, permafrost table, and permafrost temperature, as well as ground-ice thaw near the permafrost table under infrastructure, which decrease engineering stability. Therefore, the effect of engineering activities on permafrost must be forecasted to ensure engineering 
stability in engineering design. Engineering stability is studied by monitoring the permafrost and deformation in many countries. In the mid-1980s, a Canadian geological survey set up several monitoring networks to evaluate the effect of the Norman pipeline engineering on permafrost in the Mackenzie delta, Tuktoyaktuk Peninsula, and northern Alberta [51].

Furthermore, in 1991, the active layer process, permafrost temperature, seasonal thaw depth, and thaw settlement along the pipeline were monitored in the permafrost regions of Nadym areas in West Siberia, Russia, and the Mackenzie River Valley, Canada [52-54]. A scientific project focused on climate change and permafrost research in Europe was set up to study climate change, permafrost degradation, and geotechnical hazards in 1998 [55]. A monitoring network of permafrost under the effect of engineering was built to observe the permafrost change and embankment stability along QXH and Qinghai-Xizang Railway (QXR) [56,57]. In recent years, based on a summary of the important advances in QXH permafrost engineering from the 1990s to the 2000s [58], the interaction between QXH and permafrost [59], engineering geology characteristics and frozen soil processes [60,61], the effect of engineering activities on frozen soil environment [62], as well as thermal stability and thaw erosion sensitivity [63] were studied to quantitatively propose a permafrost thermal regime and heat budget under an asphalt pavement [64]. Embankment deformation and its influence factors $[65,66]$, and a summary and analysis of the newest advances in highway construction technologies in permafrost regions of QXP were also presented [67].

After QXH was constructed, the thermal effect of the asphalt pavement produced a continuously increasing permafrost table under the embankment (Figure 4(a)). Figure 4(b) shows the great difference in fluctuation increase of the permafrost table (Figure 4(b)). The change of permafrost table under the embankment is closely related with the permafrost's thermal stability (Figure 4(b)). For cold permafrost in high-middle Mountains, where the mean annual ground temperature is lower than $-1.5^{\circ} \mathrm{C}$ (e.g. $\mathrm{KM} 1, \mathrm{KM} 2$, WD2, and FH1 sites), the increasing rate of permafrost table varies from 2.1 to $9.4 \mathrm{~cm} \mathrm{a}^{-1}$, with an average of $4.8 \mathrm{~cm} \mathrm{a}^{-1}$ [68]. For warm permafrost in high plains and valleys, where the mean annual ground temperature is higher than $-1.5^{\circ} \mathrm{C}$ (e.g. the CM1, CM2, TG1, TM1, and AD1 sites), the increasing rate of permafrost table varies from 17.4 to 25.8 $\mathrm{cm} \mathrm{a} \mathrm{a}^{-1}$, with an average of $22.5 \mathrm{~cm} \mathrm{a}^{-1}$ [68]. After the asphalt pavement was constructed about 35 years in cold permafrost areas, the permafrost table under the embankment increased only $23 \mathrm{~cm}$, implying that embankment stability can be ensured by heightening the embankment to increase thermal resistance $[59,64,67]$. After the asphalt pavement was constructed in warm permafrost areas, the permafrost table under the embankment continuously increased; the maximum increase was more than $2 \mathrm{~m}$.

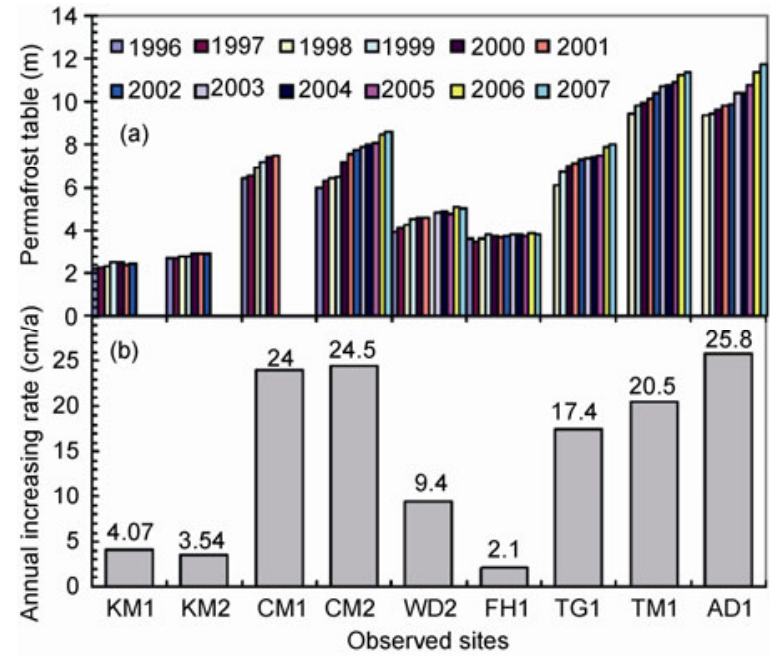

Figure 4 (a) Permafrost table beneath the embankment of QXH and (b) the annual increasing rate of permafrost table.

Obviously, until special designs are proposed, embankment stability cannot be ensured by heightening the embankment to increase thermal resistance $[59,67]$.

The engineering effect results in a larger absorbed heat of soils than release heat, showing the absorbed heat in one year [64] and leading to an increasing in permafrost temperature beneath the embankment. In recent decades, permafrost temperature beneath the QXH embankment has continuously increased (Figure 5(a) and (c)). The mean annual permafrost temperature at $6 \mathrm{~m}$ depth increased from 0.2 to $0.96^{\circ} \mathrm{C}$, with an average of $0.44^{\circ} \mathrm{C}$ during the past 12 years. Figure 5(b) shows that the increasing rate of permafrost temperature varied from 0.018 to $0.087^{\circ} \mathrm{C} \mathrm{a}^{-1}$. The mean annual permafrost temperature at $10 \mathrm{~m}$ depth increased from 0.25 to $0.54^{\circ} \mathrm{C}$, with an average of $0.37^{\circ} \mathrm{C}$ during the past 12 years. Figure 5(d) shows that the increasing rate of permafrost temperature varied from 0.022 to $0.052^{\circ} \mathrm{C} \mathrm{a}^{-1}$ [68]. The changes in permafrost temperature have a regional difference; the increasing fluctuation of permafrost temperature in middle-high mountains is smaller than that in high plains and valleys [56]. Nonetheless, this trend is applicable in the Nothern Tanggula Mountains.

The response of permafrost to climate change and to engineering activities has a great difference. Engineering activities are short-term, quick-effect processes on permafrost, whereas climate change is a long-term, slow-effect process on permafrost. For cold permafrost in middle-high mountains, the effect of climate change on the permafrost table and temperature is larger than that of engineering activities (Figure 6). For warm permafrost in high plains and valleys, the effect of engineering activities on the permafrost table and temperature is larger than that of climate change (Figure 6). This disparity in effect is a result of engineering activities significantly enlarging permafrost change during the first few years after engineering construction. However, after the effect of engineering activities on permafrost is 

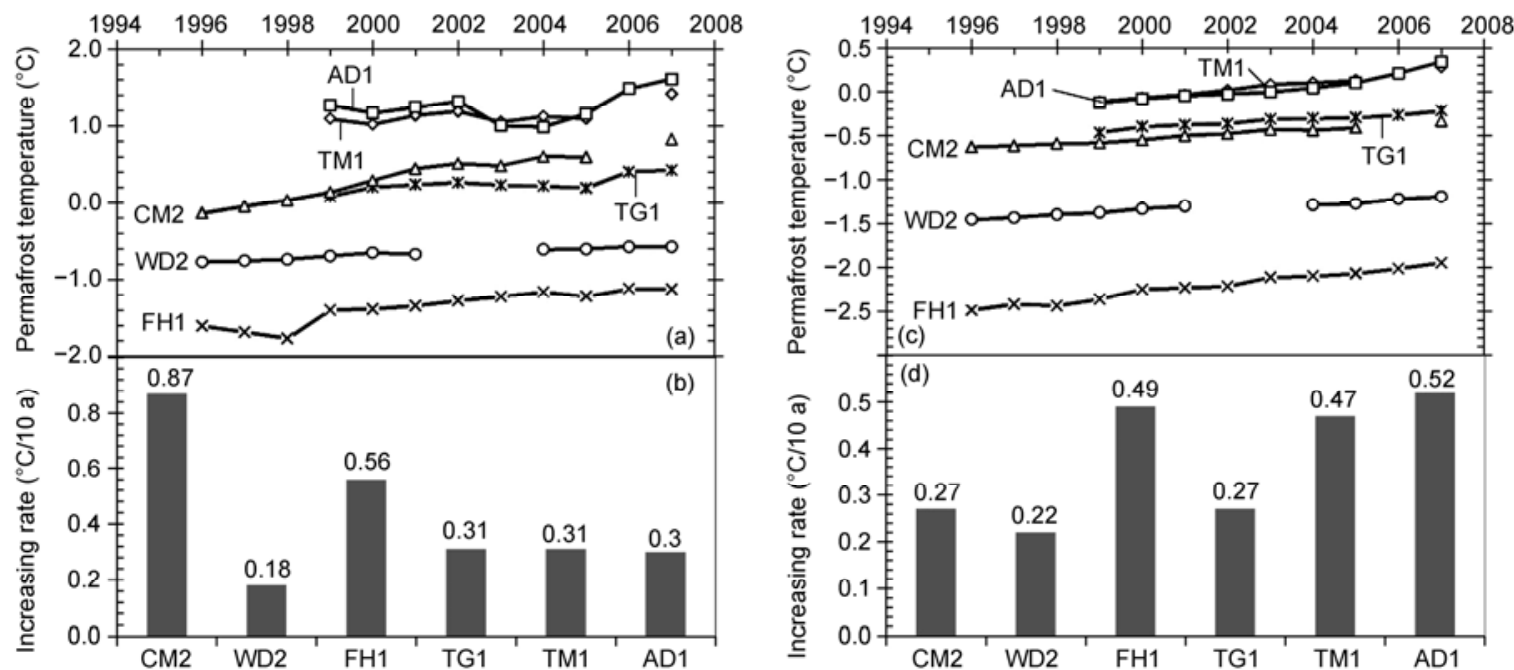

Figure 5 (a) Mean annual permafrost temperature at $6 \mathrm{~m}$ depth beneath the embankment; (b) annual increase rate of permafrost temperature; (c) mean annual permafrost temperature at $10 \mathrm{~m}$ depth beneath the embankment; (d) the increasing rate of permafrost temperature.
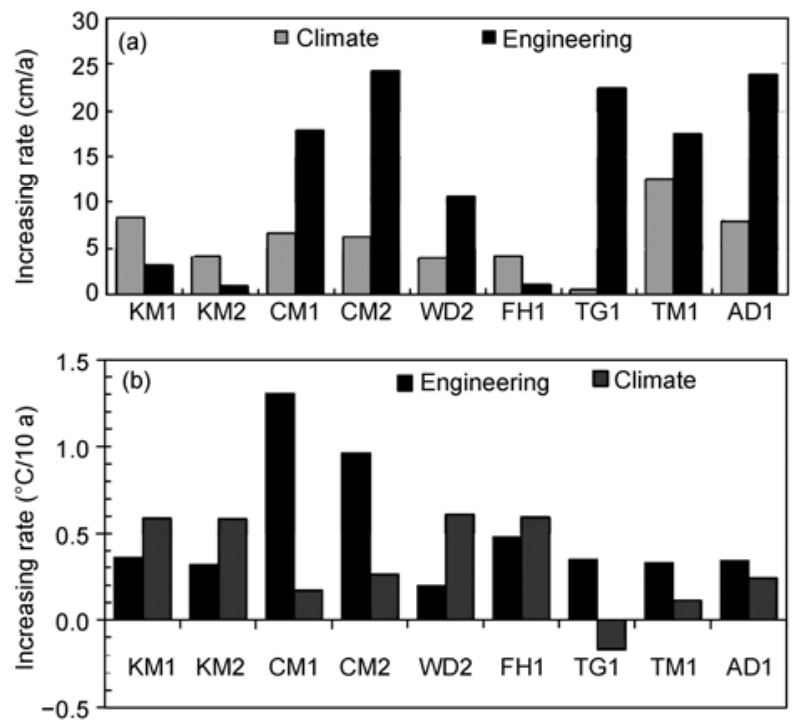

Figure 6 (a) Permafrost table and (b) permafrost temperature at $6.0 \mathrm{~m}$ depth under the effect of climate change and engineering.

reduced, the effect of climate change on permafrost will gradually occur. Assuming constant annual rates of permafrost warming under climate change, 30 to 50 years will pass before cold permafrost under engineering undergoes the combined influence of climate change and engineering activities, whereas warm permafrost only need 20 years [56]. According to the approximately 30-year history of QXH construction, warm permafrost experiences a combined influence of climate changes and engineering activities, but cold permafrost does not. Therefore, the change of warm permafrost is controlled by the coupling action of long-term climate change and short-term engineering of activities. Embankment stability is greatly changed because of the permafrost change under engineering. Embankment defor- mation is closely related to the thermal stability of permafrost. The rate of embankment deformation reaches as much as 4 to $10 \mathrm{~cm} \mathrm{a}^{-1}$ for the permafrost areas with a mean annual ground temperature higher than $-1.5^{\circ} \mathrm{C}$, where it is less than $4 \mathrm{~cm} \mathrm{a}^{-1}$ for the permafrost areas with a mean annual ground temperature lower than $-1.5^{\circ} \mathrm{C}[59,65,66]$. Thawing permafrost with high ice content (volume ice content is more than $25 \%$ ) results in a large embankment deformation. In addition, the amount of thaw settlement is positively correlated with the permafrost thawing rate, which has a correlation coefficient of more than 0.85 [68], indicating that most embankment deformation is caused by permafrost thawing.

\section{Dynamic change of QXR engineering stability}

The engineering surfaces of QXH and QXR have significant differences. The asphalt pavement of QXH is relatively close and impermeable to air and water, but the ballast of QXR is permeable to air and water. Therefore, the effect of QXR on the thermal-mechanical stability of permafrost under embankment is not the same as that of QXH. QXH and QXR face highly sensitive issues such as the effect of climate change and engineering activities on warm permafrost with high ice content $[14,69]$. Thus, focusing on the effect of engineering on permafrost will have a considerable difference to QXH and QXR because of their usage lifetime and service performance. To solve the highly sensitive issues mentioned, the design ideas of a cooling roadbed and decreasing the permafrost temperature are proposed [70]. A cooling roadbed can be achieved through geotechnical measurements of adjusting and controlling heat conduction, convection, and radiation $[13,17,18]$. Owing to the difficulty and complexity of QXR construction, a dynamic feed- 
back design is proposed, and QXR designs are optimized by the repeated cycles of "design-monitoring-predictionfeedback management" [71]. Design parameter, monitoring, and prediction are the keys to achieving a cooling roadbed and decreasing the permafrost temperature.

During the early periods of QHX construction, three experimental sections were built at Qingshuihe, Beiluhe, and Tuotuohe, and numerous geotechnical measurements were studied to evaluate the protective effect of these sections to permafrost under engineering [72,73]. A heat insulator paved within the embankment can delay permafrost thawing beneath the embankment, though the roadbed stability cannot be completely solved $[74,75]$. A combined thermosiphon and heat insulator can better remedy the imperfection of a heat insulator, which relies purely on thermal resistance to protect the permafrost beneath the embankment and accommodate the effect of climate change [76,77]. Thermosiphon, a one-way heat conducting-device that can bring the heat amount out of the embankment by conducting a "cooling amount" of air in winter into the embankment, has a better effect on the cooling roadbed. It is widely used in permafrost regions in Canada and the US [78-80] as well as in QXH and QXR [81-84]. Ventiduct embankments can effectively decrease permafrost temperature beneath the embankment by enforcing convection $[85,86]$, which shows an ability to adapt to climate change [87-89]. Crushed-rock structure embankments such as crushed-based rock embankments (CBREs), crushed-rock and debris covers, and U-shape crushed-rock embankments can better protect permafrost beneath the embankment, which will not thaw when the air temperature increases to $2.6^{\circ} \mathrm{C}$ in the next 50 years [90-93]. Therefore, these measures are widespread in the permafrost regions of QXR [72]. Shading boards and awnings can effectively decrease permafrost temperature by reducing the solar radiation of embankment surfaces. The mean temperature of embankment slope surfaces inside shading boards is lower by 3.2 and $1.5^{\circ} \mathrm{C}$ than those without shading boards and those with natural surfaces, respectively, thus reducing heat amount into the embankment $[13,94,95]$. In recent years, some new embankment structures of the cooling roadbed have been proposed [96]. Engineering measures of the cooling roadbed have a significant role in protecting the permafrost beneath the embankment for the construction and design of QXR.

Thermal and mechanical stability was one of the most important research foci during the period of QXR operation. Therefore, observation systems for permafrost embankment stability along QXR were built to monitor the permafrost's dynamical change of thermal and mechanical stability beneath the embankment, as well as the difference of solar radiation between the sunny and shaded slopes [57,97]. These systems illustrate the dynamical processes of permafrost change beneath the embankment and of embankment deformation [98-102].

\subsection{Thermal regime of permafrost and embankment deformation of QXR}

The monitoring results of permafrost temperatures show that the protective effect of crushed-based rock on permafrost beneath the embankment is predominantly different and closely related to the thermal stability of permafrost. For stable cold permafrost regions where the mean annual ground temperature is lower than $-2.0^{\circ} \mathrm{C}$, permafrost beneath the crushed-based rock and general embankments have an obviously decreasing trend (Figure 7(a) and (b)). This finding indicates that one part of the cooling amount in the crushed-based rock and general embankments is used to freeze the soil layer thawed in summer, and a residual part can be used to decrease permafrost temperature beneath the embankment [98,99]. For the CBRE, the mean annual rate of decreasing permafrost temperature varied from 0.088 to $0.11^{\circ} \mathrm{C} \mathrm{a}^{-1}$ during the period of 2006 to 2010 and gradually increased with a depth above $5.0 \mathrm{~m}$ depth, while the permafrost at $10.0 \mathrm{~m}$ depth beneath the embankment had an obvious decrease (Figure 7(a)). For the general embankment, the mean annual decreasing rate of permafrost temperature varied from 0.10 to $0.13^{\circ} \mathrm{C} \mathrm{a}^{-1}$ during the period of 2006 to 2010 and gradually decreased with depth [103]. The permafrost table beneath the crushed-based rock and general embankments also rose into the embankment. A newly formed permafrost table is also relatively stable and soil temperatures near the permafrost table have a predominantly decreasing trend. The embankment deformation mainly shows frost heave; the total amount of frost heave is lower than 2 $\mathrm{cm}$, indicating a stable embankment [100].

For basically stable cold permafrost regions where the mean annual ground temperature varies from -1.0 to $-2.0^{\circ} \mathrm{C}$, permafrost beneath the crushed-based rock and general embankments have an obviously decreasing trend (Figure 8(a) and (b)). However, the decreasing fluctuation of permafrost temperature beneath the CBRE is larger by 1.0 to $1.5^{\circ} \mathrm{C}$ than that beneath the general embankment $[98,99,101,102]$. For the CBRE, the permafrost table has a predominant rise while the soil temperature near the newly formed permafrost table has an obviously decreasing trend. For the general embankment, the permafrost table predominantly rises. However, the rising fluctuation of the permafrost table beneath the general embankment is smaller than that beneath the CBRE while the soil temperature near the newly formed permafrost table is basically stable. Embankment deformation mainly shows thaw settlement. During the five-year observation period, the total amount of deformation was smaller than $5 \mathrm{~cm}$, indicating that the embankment is stable. However, the deformation of a general embankment is larger than that of the CBRE and is predominantly uneven [100].

For unstable warm permafrost regions where the mean annual ground temperature is higher than $-1.0^{\circ} \mathrm{C}$, permafrost beneath the crushed-based rock and general embankments 


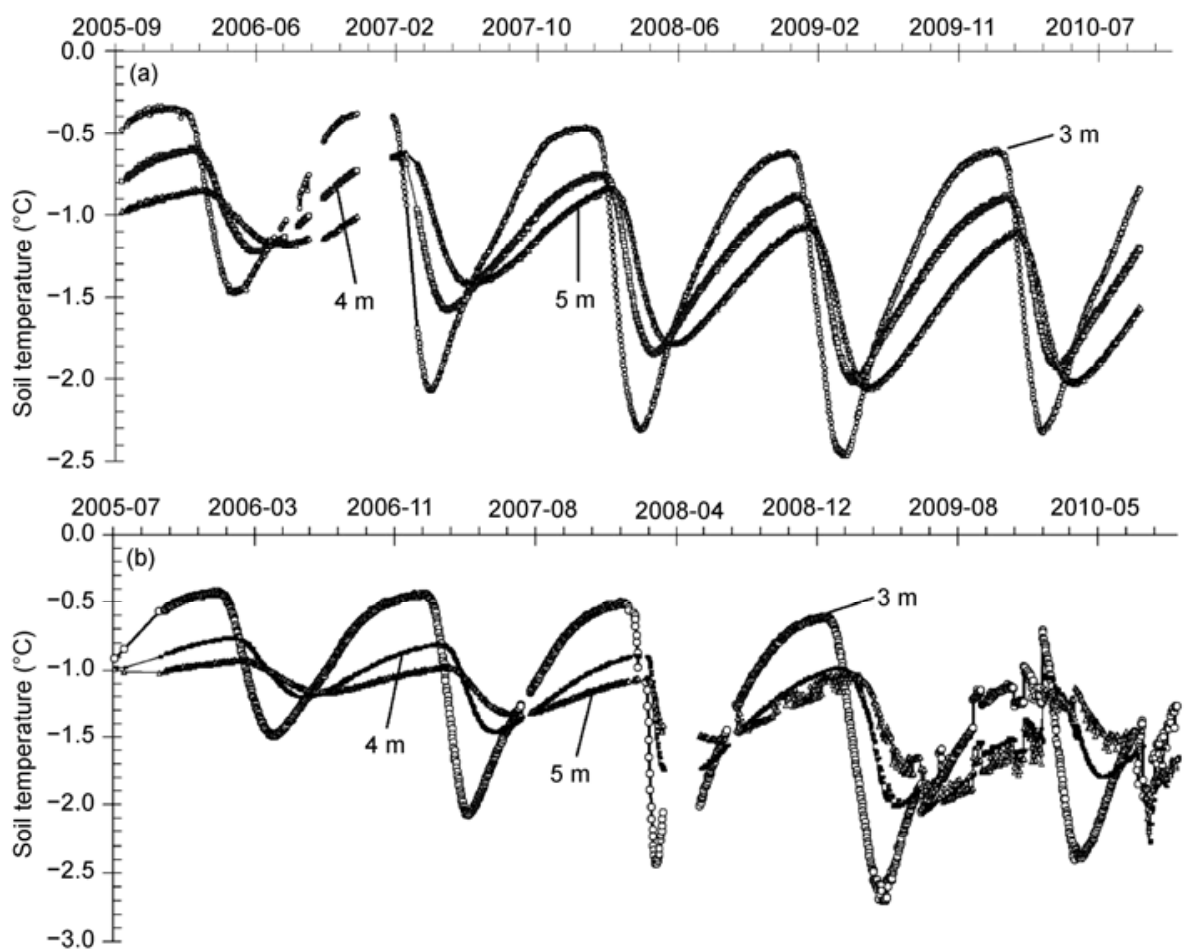

Figure 7 (a) Change of permafrost temperature beneath the CBRE and (b) the general embankment in cold permafrost regions.

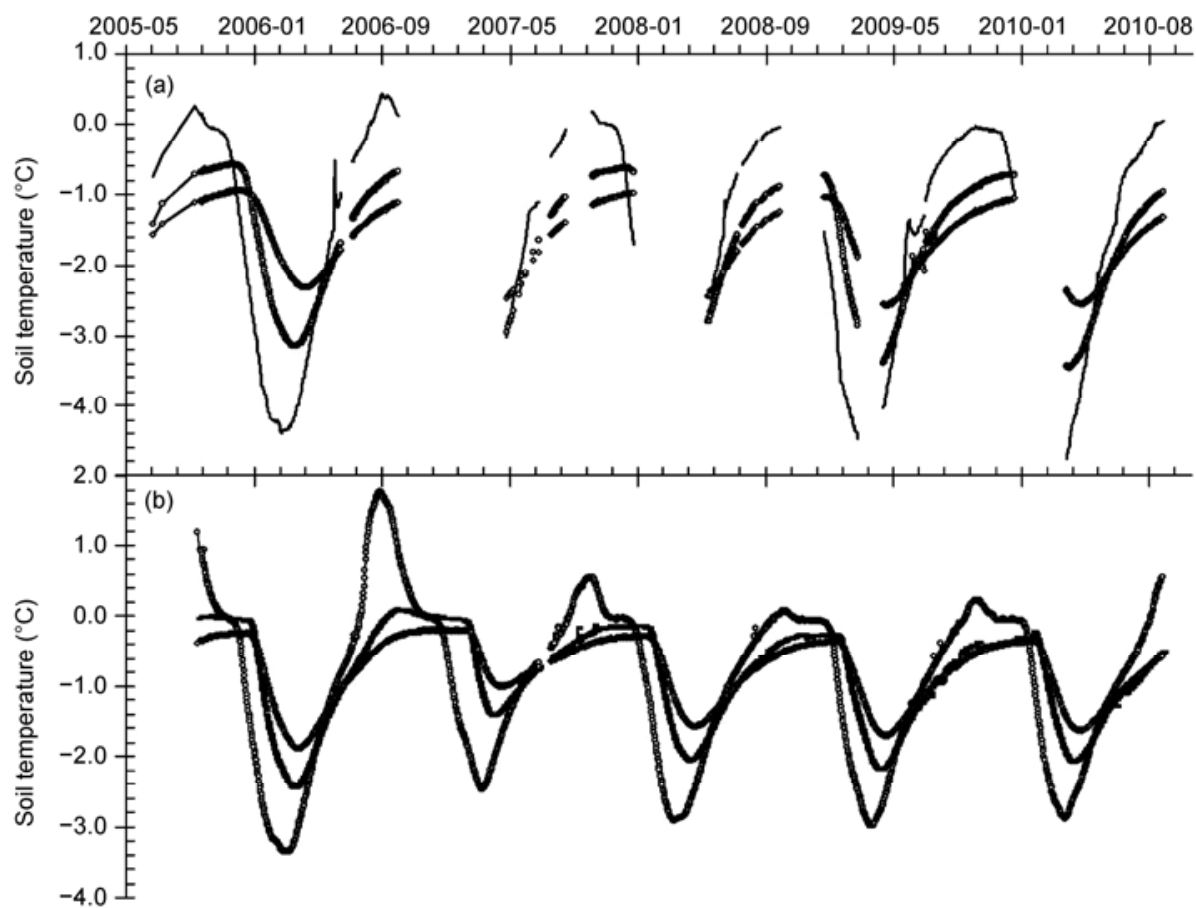

Figure 8 Change of permafrost temperature beneath (a) the CBRE and (b) the general embankment in basically stable cold permafrost regions.

have a slightly decreasing trend, but the decreasing fluctuation of permafrost temperature is smaller than that of cold permafrost. Permafrost temperature does not show a predominantly increasing trend because crushed-rock embankments gradually produce the effect of protecting permafrost beneath the embankment because of the perma- frost's poor thermal stability [98-101]. Therefore, embankment deformation is basically stable with only a slight differential deformation. At the same depth, the soil temperature in general embankments is higher by about $2^{\circ} \mathrm{C}$ than that in CBREs and has a predominantly increasing trend. The original thermal balance of soil is changed under 
the influence of engineering disturbance or soil thermal resistance of the embankment, resulting in the increase in soil temperature beneath the embankment and a decrease in the permafrost table $[98,103]$. Permafrost thawing beneath the embankment produces a deformation more than $5 \mathrm{~cm}$, though more than $10 \mathrm{~cm}$ in five sections are observed [100].

Generally, CBREs can effectively decrease permafrost temperature and increase permafrost table while ensuring that the embankment is stable. General embankments decrease permafrost temperature and increase permafrost table in cold permafrost regions. Permafrost temperature has an increasing trend in warm permafrost regions, whereas permafrost table has a decreasing trend. Such changes lead to large deformation and large differential deformation, greatly affecting embankment stability.

\subsection{Thermal effect of sunny and shaded slopes of embankment}

The differences in solar exposure produce a predictable thermal effect on the sunny and shading slopes of the embankment, which result in differences in soil temperature and permafrost table under the shoulder [104,105] and numerous engineering problems such as uneven deformation and longitudinal crack of the embankment in permafrost regions $[66,106,107]$. The difference of soil thermal regime in an embankment slope results in the difference between the freezing and thawing characteristics of soil beneath the embankment [106,107]. Results show that the difference of subsurface soil temperature between sunny and shading slopes of the embankment is closely related with solar radiation [108]. A special design that considers the differential thickness of crushed-rock cover can be used to reduce the thermal effect of sunny and shading slopes, thus gradually making the soil temperature uniform beneath the embankment and reducing uneven deformation [109].

The monitoring results of permafrost temperature along QXR show that permafrost temperatures and the permafrost table beneath the embankment have a large difference, and such difference in cold permafrost regions is predominantly larger than that in warm permafrost regions. The permafrost table beneath the sunny slope of the embankment is deeper by 1.5 to $2.0 \mathrm{~m}$ than that beneath the shading slope of the embankment, which indicates a sloping interface of freezing-thawing beneath the embankment [110]. The soil temperature difference between the sunny and shading slopes of the embankment for all monitoring sections along QXR varies from 0.5 to $3.0^{\circ} \mathrm{C}$. Engineering measures can significantly reduce the thermal effect of sunny and shading slopes. The mean difference of soil temperature between the sunny and shading slopes of embankment is about 0.7 to $1.58^{\circ} \mathrm{C}$ for the general embankment without measures, and about 0.23 to $1.2^{\circ} \mathrm{C}$ for the embankment with measures. The soil temperature difference between the sunny and shading slopes of the embankment is mainly caused by the soil temperature difference in winter [110]. The calculated results of all the sections show that the difference of solar radiations and surface temperature between sunny and shading slopes is positively correlated with embankment orientation (Figure 9). This result gives us important predictions, which embankment design in permafrost regions can use to account for the influence of embankment orientation on the thermal effect of sunny and shading slopes [110].

\subsection{Cooling process and mechanics of crushed-rock structure}

Crushed-rock structure embankment is one of the geotechnical measures widely applied in the permafrost regions of QXR, including CBRE, crushed and debris rock cover, U-shaped crushed-rock embankment [17,70,71], and so forth. However, the cooling mechanics of crushed-rock structures are unclear during the early period of QXR construction. In nature, soil temperature beneath the crushedrock layer has a better decreasing trend [111-113], usually resulting in permafrost occurrence in the areas where mean annual air temperature is higher than $0^{\circ} \mathrm{C}$; such cooling phenomenon depends on the "chimney" effect of the crushed-rock layer on the slope [114]. Therefore, Cheng et al. [115-117] constructed an experimental section to study the cooling effect of a crushed-rock embankment on permafrost at the Reshui coal mine in Qilian Mountains. Gering et al. [118,119] set up an experimental section of air convection embankment (crushed-rock layer) with asphalt pavement to study the cooling mechanism in Alaska. Their research results show that air convection affects the crushedrock layer, and such effect results in a large decrease of

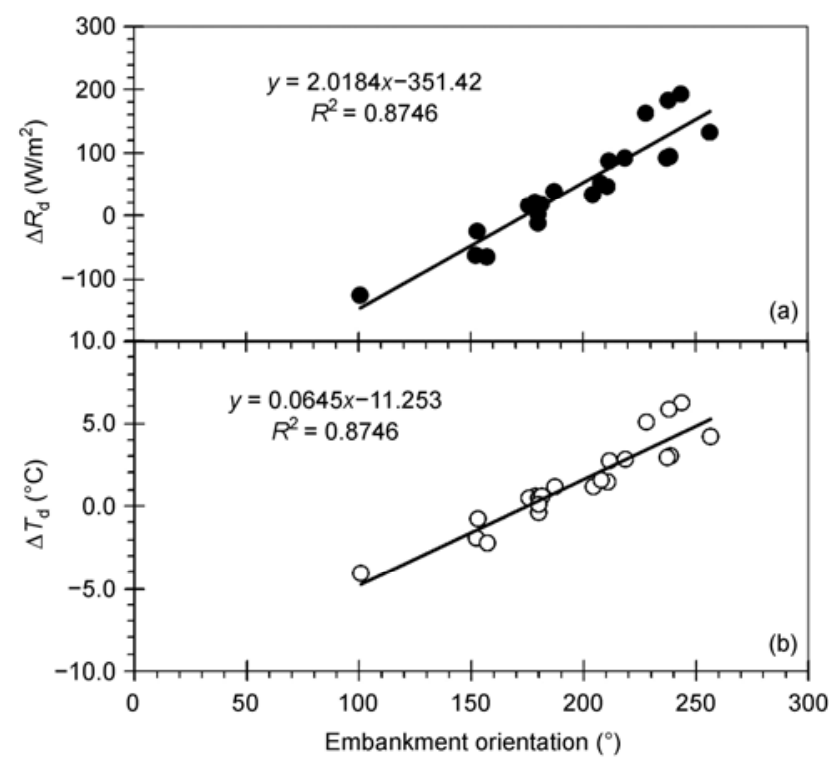

Figure 9 Embankment orientation versus the difference of (a) solar radiation and (b) slope surface between sunny and shaded embankment slopes along QXR. 
permafrost temperature beneath the air convection embankment. At the same time, numerical simulation was conducted to find the mechanism of air convection within the crushed-rock layer [120]. For QXR, the soil layer underlying the crushed-rock layer needs to be filled, namely, CBRE [72], and the crushed-rock layer is paved on embankment slopes, namely, crushed-rock cover. However, several important problems during the early periods of QXR construction, such as the cooling mechanism, the effect of crushed-rock structure embankment on permafrost, and the cooling effect after the crushed-rock layer is jammed by sand, are still unclear. Therefore, experimental sections of crushed-rock structure embankment were constructed in permafrost regions with a thick-layer ground ice in Beiluhe to focus on the cooling mechanism and effect on permafrost beneath the embankment under open and close conditions of the crushed-rock layer [121-123]. In these regions, open conditions mean that the crushed-rock layer connects with the air outside and close conditions mean that the crushedrock layer does not connect with the air because it is paved with a soil layer $5 \mathrm{~cm}$ thick.

(1) Crushed-based rock embankment (CBRE). The design and construction of a CBRE require a large interspace.
The experimental results show that the void ratio of a crushed-rock layer with an average grain size of $10 \mathrm{~cm}$ to $15 \mathrm{~cm}$ is about $45 \%$ [124]. According to the monitoring data from experimental sections in Beiluhe, the cooling mechanism of the open-system CBRE shows a combined process of enforcing convection of extensive ventilation and weak air convection in the northwest-facing side of the embankment in winter (Figure 10(a)), which is closely related to wind speed and directions (Figure 11(a)-(c)) [121-123]. When the wind speed is large, the enforcing convection of ventilation occurs. When the wind speed is small, the weak air convection occurs in the northwest-facing side of the embankment. Weak enforcing convection within the CBRE occurs due to the small wind speed in summer. Heat conduction usually occurs within the CBRE in summer, and a large interspace within the crushed-rock layer causes the effect of heat insulation. Therefore, CBRE can produce extensive cooling effect to permafrost beneath the embankment under the effect of such cooling mechanism mentioned. Moreover, soil temperatures have an extensively decreasing trend and the decrease of soil temperature at $10 \mathrm{~m}$ depth beneath the embankment is dominant [121-123]. However, the enforcing convection process within the close-system

(a)

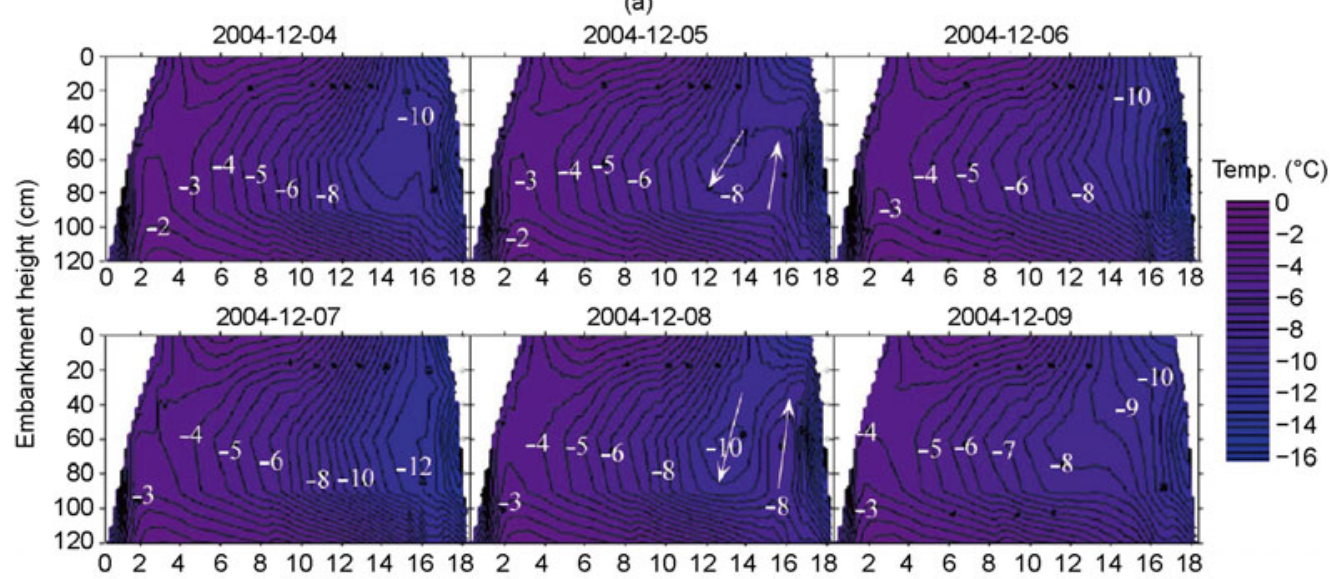

(b)

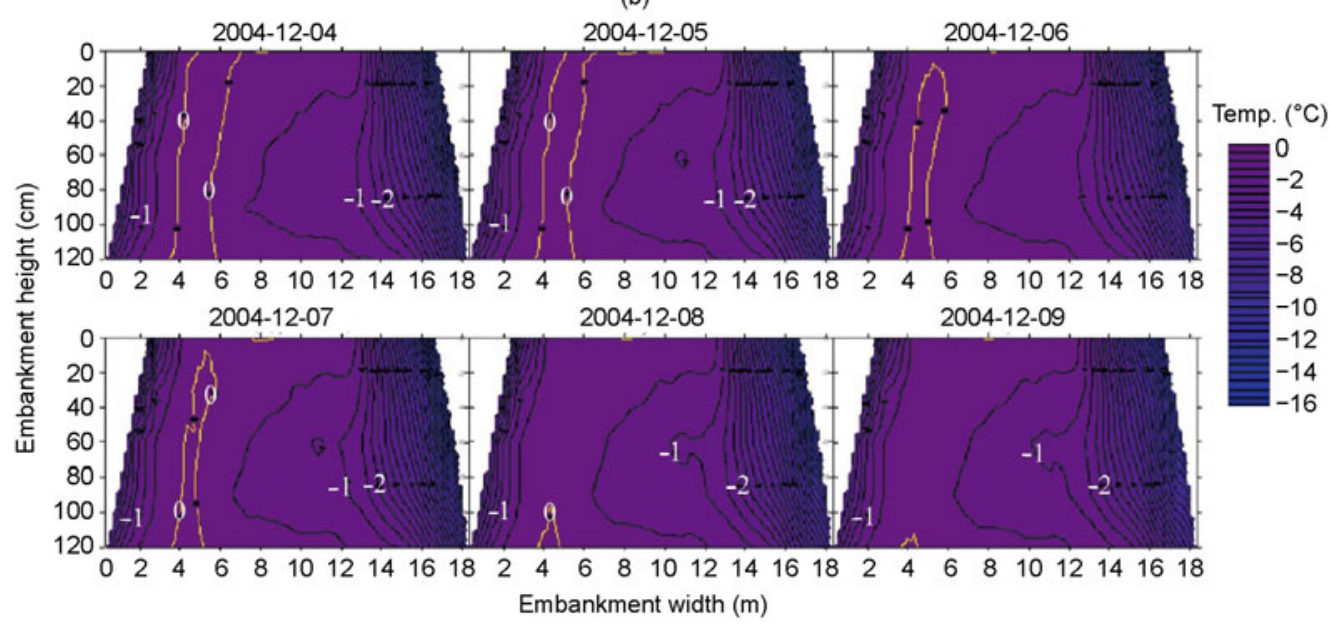

Figure 10 (a) Open-system and (b) close-system CBRE isotherm. 


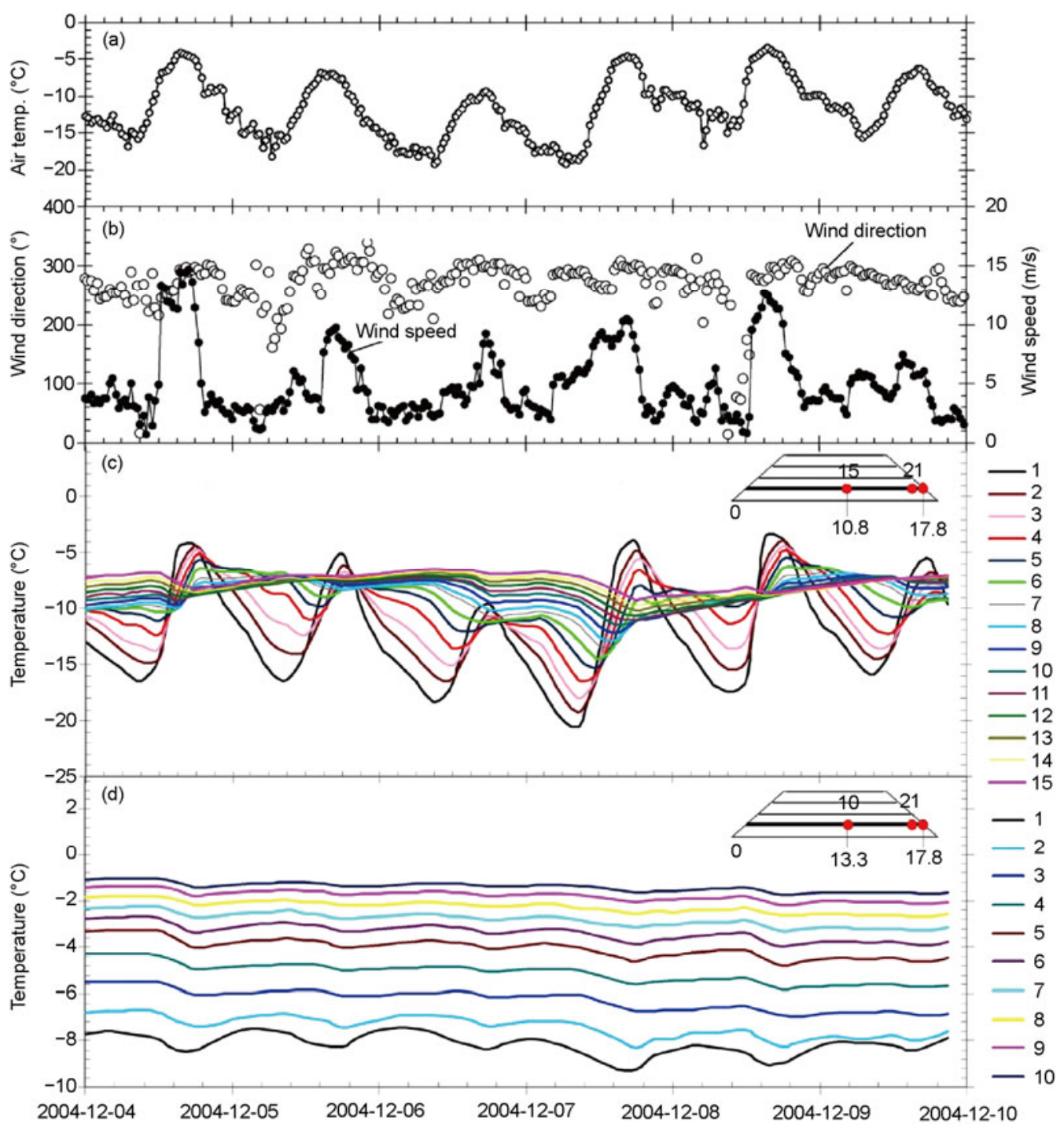

Figure 11 (a) Winter air temperature, (b) wind speed, (c) open-system, and (d) close-system temperature change within a crushed-rock layer.

CBRE is weakened due to the prevention or weakening of the wind effect (Figure 10(b)). In comparison, the temperature difference between the top and bottom of the crushedrock layer cannot sufficiently enforce air convection because of the effect of the soil that fills the underlying embankment (Figure 11(d)). Therefore, the heat conduction process is dominant within the close-system crushed-rock layer, and a large interspace within the crushed-rock layer show a better heat insulation effect. Although enforcing convection cannot be produced within the close-system CBRE, soil temperatures beneath the embankment show a decreasing trend due to extensive heat insulation (Figure 12). The cooling effect of the close-system CBRE is much smaller than that of the open system [121-123].

(2) Crushed-rock cover embankment. After the opensystem crushed-rock layer is paved on the embankment slope, a chimney effect, an air connection, can be produced within the crushed-rock layer through the large interspace under the enforced temperature difference and air density difference [125]. Air convection with a swirling isotherm appears within the open-system crushed-rock cover in all seasons (Figure 13) [123,126]. Heat insulation with a dense parallel isotherm also appears within the open-system crushed-rock cover in all seasons (Figure 14) [123,126]. The time that air convection and heat insulation within the crushed-rock cover occurs has a large difference for all seasons, and the chimney effect and heat insulation effect have predominantly daily changes. The heat insulation effect mainly occurs in the period of air temperature increase at 9:00 to 18:00 in summer and autumn, showing an advantage effect to protect permafrost beneath the embankment. However, this effect occurs in the period of air temperature decrease at 24:00 to 9:00 in winter, which shows the disadvantage effect to protect permafrost. In summer, it is difficult to determine the time that heat insulation occurs because of the continually changing air temperature. The air 


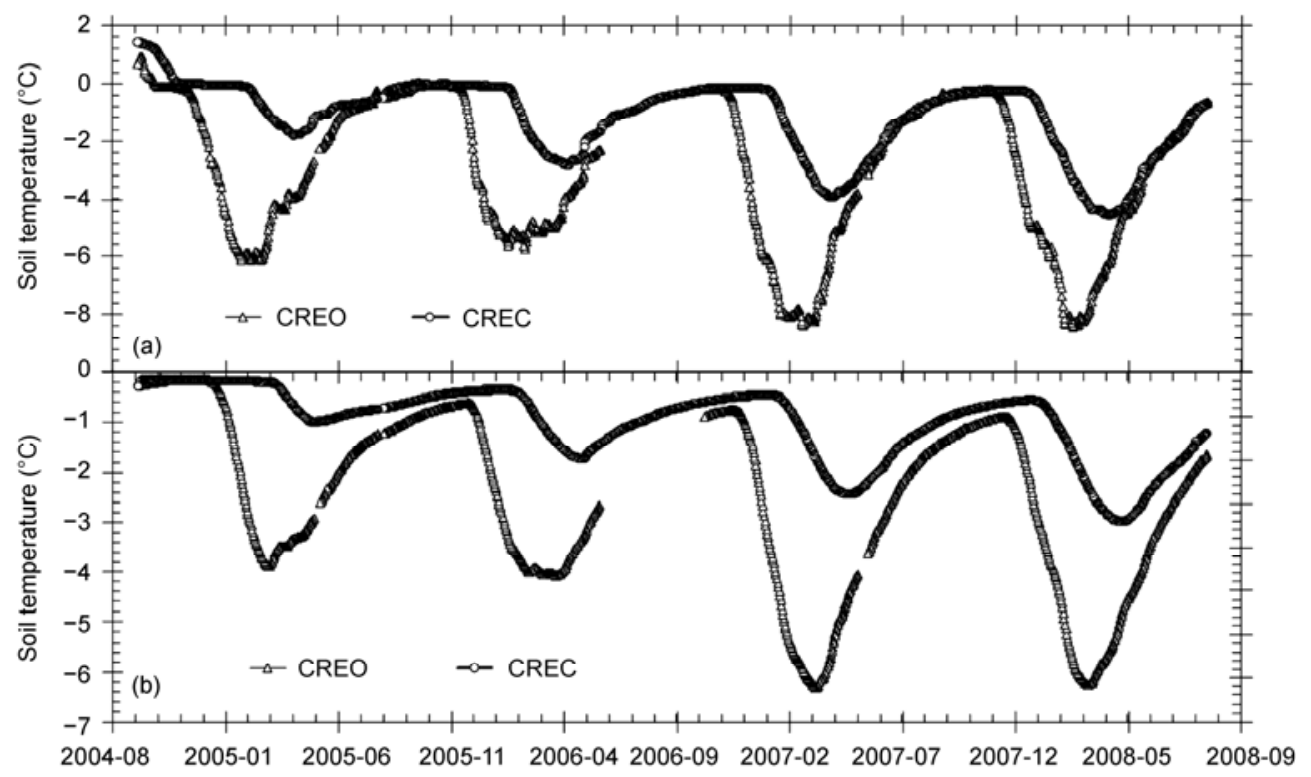

Figure 12 Soil temperature at (a) $0.5 \mathrm{~m}$ depth and (b) $2.5 \mathrm{~m}$ depth beneath the embankment. CREO refers to the open-system crushed-based rock, and CREC refers to the close-system CBRE.
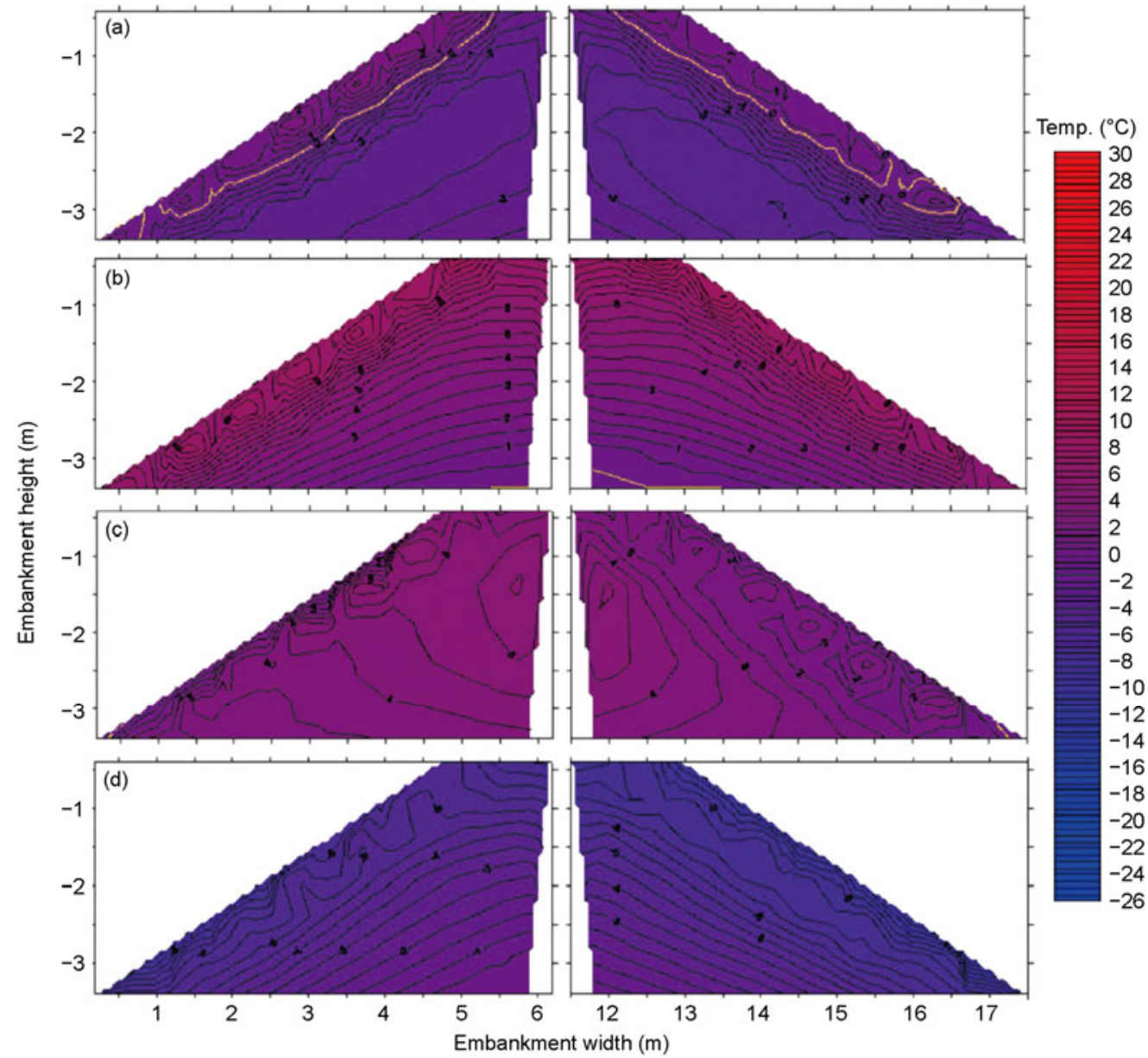

Figure 13 Air convection within crushed-rock cover in (a) spring, (b) summer, (c) autumn, and (d) winter. 


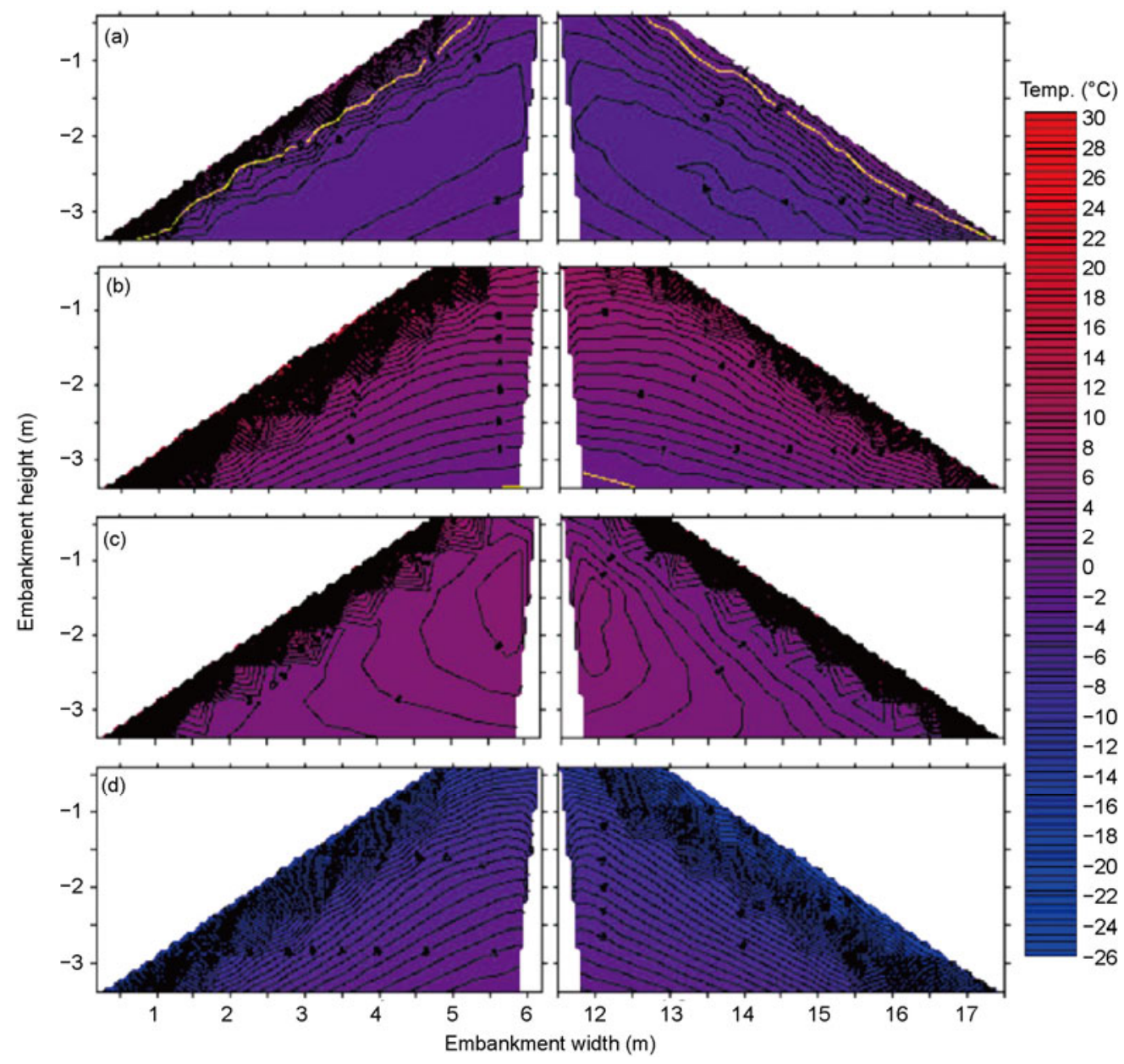

Figure 14 Heat insulation within crushed-rock cover in (a) spring, (b) summer, (c) autumn, and (d) winter.

convection effect mainly occurs in the period of air temperature decrease at 18:00 to 24:00 in spring, summer, and autumn, showing an advantage effect to protect permafrost. However, the effect occurs in the period of high air temperature at 12:00 to 18:00 in winter, showing an advantage effect to protect permafrost due to the negative air temperature in winter [123]. Therefore, with the seasonal changes of air temperature and the daily change of air temperature difference, the heat insulation effect and chimney effect within the crushed-rock cover show a combined process of daily and seasonal changes. Such process results in the change of heat amount transferred within the crushed-rock cover, which, in turn, results in a change of the permafrost's thermal regime beneath the embankment. After the crushedrock cover is jammed by sand, the cooling mechanism is weakened. After the thickness of the crushed-rock cover is increased, the cooling mechanism is strengthened.

A crushed-rock layer is paved on an embankment slope, and the thermal disturbance of its soil temperature within the embankment changes with the air temperature, which affects the cooling effect of this structure. This prevents the soil temperature beneath the embankment from decreasing quickly in the short term (Figure 15). Meanwhile, the dif- ferences of soil temperature decrease among the opensystem, close-system, and thickening crushed-rock covers are small in the early period of engineering construction. However, the cooling effect of the crushed-rock cover gradually accumulates with time, the soil temperatures gradually decrease, and the soil temperature differences among the open-system, close-system, and thickening crushed-rock covers gradually increase (Figure 15) [122].

\section{Discussions}

Climate change clearly affects frozen soil engineering, which needs to account for climate change to ensure longterm stability and reliability. Climate change must be seriously considered in engineering design. When QXH was constructed, no consideration was given to the influence of climate change on the design of embankment height and engineering measure; it was just in the last decade that this factor was considered when it led to thaw settlement, a major engineering disease. Although the QXR construction has now considered the effect of climate change and ecological environment change on permafrost, the main principle is 


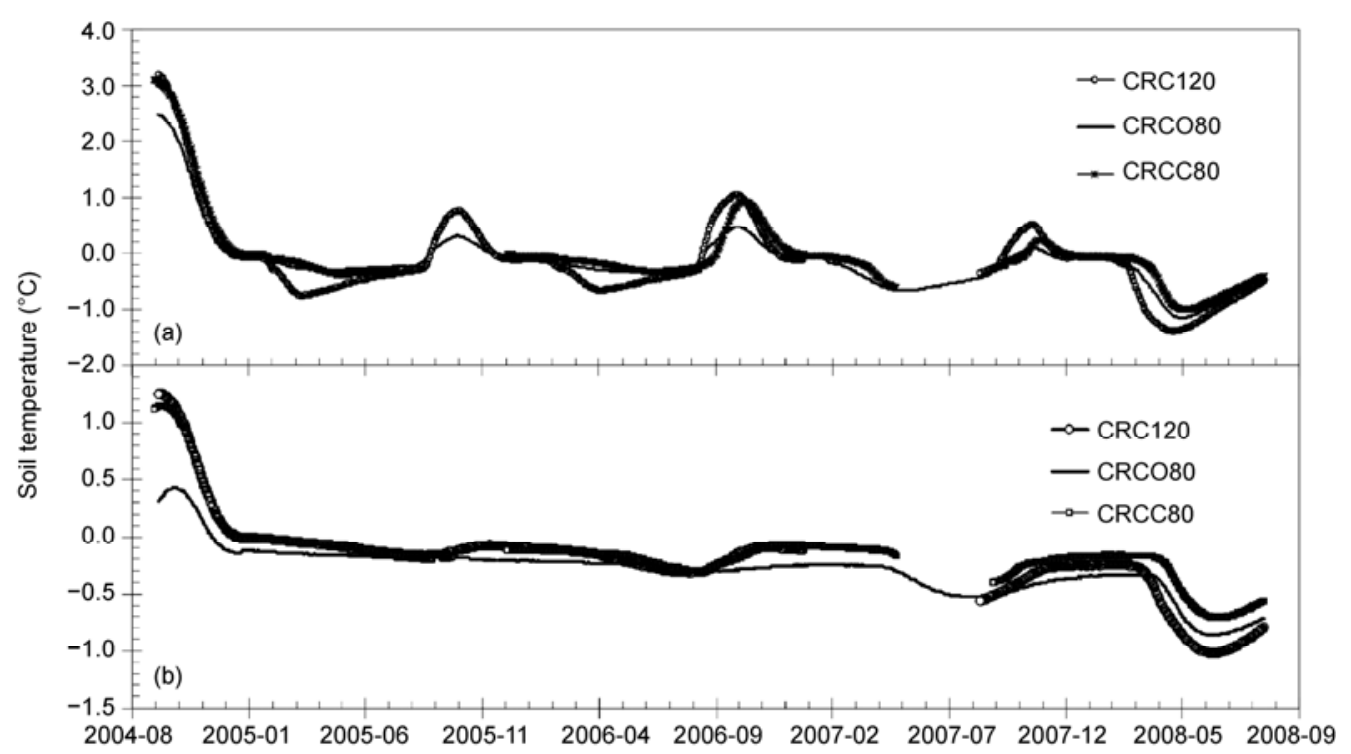

Figure 15 Soil temperatures at (a) $0.5 \mathrm{~m}$ depth and (b) at $2.5 \mathrm{~m}$ depth beneath the crushed-rock cover embankment. CRC120 refers to crushed-rock cover that is $120 \mathrm{~cm}$ thick; CRCO80 and CRCC80 refer to open-system and close-system crushed-rock covers that are $80 \mathrm{~cm}$ thick, respectively.

proposed in engineering design because we cannot evaluate and determine the overlapping influence of climate change and engineering thermal disturbance on permafrost beneath the embankment, as well as the contribution of this overlapping influence to engineering stability. Therefore, the rationality of engineering design and the adaptability of climate change are only evaluated by monitoring permafrost change after construction, which leads to the large uncertainty of considering climate change in future engineering design. The methods and ideas of engineering design in considering climate change are difficult to apply in a wide scale.

Climate change and engineering activities lead to ecological environment changes in permafrost regions. These changes, in turn, induce the local settlement of the ground surface and affect engineering stability in the cold regions. As of this writing, we cannot rationally reveal the source of large deformation for roadbed engineering, specifically, whether the deformation source is related to the settlement of ground surface caused by climate change and engineering activities. On the other hand, engineering activities lead to changes in the frozen soil environment, which then induce ecological environment changes including vegetation degradation, desertification, and so on. Although environment protection measures and cooling roadbeds do not wield a large impact on ecological systems, they may have longterm potential influence on the ecological environment and the range of their influence may extend from local scale to regional scale. Thus, we urgently need to determine methods for considering the effect of sensitive ground surface settlement in the engineering design for cold regions.

Under the effect of ecological environment change and climate change, we need to include permafrost, climate, environment, and engineering into a system to synthetically analyze their interactions. The mechanism of overlapping effects of climate change, engineering activities, and ecological environment change on engineering stability, the response process as well as the mechanism of thermal and mechanical stability of permafrost to climate change, ecological environment change, and engineering activities are difficulties that result in a bottleneck. The restrictions to taking into consideration climate change and ecological environment in the engineering design for frozen soil, and the tendency of future research to focus on frozen soil engineering must be urgently addressed.

This work was supported by the Outstanding Youth Foundation Program of the National Natural Science Foundation of China (40625004), the Global Change Research Program of China (2010CB951402), and the State Key Program of the National Natural Science Foundation of China (41030741).

1 Zhang T, Barry R G, Knowles K, et al. Statistics and characteristics of permafrost and ground-ice distribution in the Northern Hemisphere. Polar Geogr, 1999, 23: 132-154

2 Zimov S A, Schuur E A G, Chapin F S. Permafrost and the global carbon budget. Science, 2006, 312: 1612-1613

3 Lachenbruch A H, Marshall B V. Changing climate: Geothermal evidence from permafrost in the Alaskan Arctic. Science, 1986, 234 : 689-696

4 Nelson F E, Anisimov O E, Shiklomanov N I. Climate change and hazard zonation in the circum-Arctic permafrost regions. Nat Hazards, 2002, 26: 203-225

5 Jorgenson M T, Racine C H, Walters J C, et al. Permafrost degradation and ecological change associated with a warming climate in central Alaska. Clim Change, 2001, 48: 551-557

6 Cheng G D, Wang S L. On the zonation of high-altitude permafrost in China. J Glaciol Geocryol, 1982, 4: 1-17

7 Zhou Y W, Guo D X, Qiu G Q, et al. Geocryology in China. Beijing: Sciences Press, 2000. 449

8 Wang G X, Li Y S, Wu Q B, et al. Impacts of permafrost changes on alpine ecosystem in Qinghai-Tibet Plateau. Sci China Ser D: Earth 
Sci, 2006, 49:1156-1169

9 Cheng G, Wu T. Responses of permafrost to climate change and their environmental significant, Qinghai-Tibet Plateau. J Geophys Res, 2007, 112: F02S03

10 Wu Q, Zhang T. Recent permafrost warming on the Qinghai-Tibetan Plateau. J Geophys Res, 2008, 113: D13108

11 Harris R B. Rangeland degradation on the Qinghai-Tibetan Plateau: A review of the evidence of its magnitude and causes. J Arid Environ, 2010, 74: 1-12

12 Sheng Y, Zhang J M, Liu Y Z, et al. Thermal regime in the embankment of Qinghai-Tibet Highway in permafrost regions. Cold Regions Sci Technol, 2002, 35: 35-44

13 Wu Q B, Cheng G D, Ma W, et al. Technical approaches on permafrost thermal stability for Qinghai-Tibet Railway. Geomech Geoeng: Int J, 2006, 1: 119-127

14 Wu Q B, Cheng G D, Ma W. Impact of permafrost change on the Qinghai-Tibet Railroad engineering. Sci China Ser D: Earth Sci, 2004, 47: 122-130

15 Tong C J, Wu Q B. The effect of climate warming on the QinghaiTibet Highway. Cold Reg Sci Technol, 1996, 24: 101-106

16 Cheng G D. Interaction between Qinghai-Tibet Railway engineering and permafrost and environmental effects. Bull Chin Acad Sci, 2002, 1: $21-25$

17 Ma W, Cheng G D, Wu Q B. Preliminary study on technology of cooling foundation in permafrost regions. J Glaciol Geocryol, 2002, 24: $579-587$

18 Cheng G D. A roadbed cooling approach for the construction of Qinghai-Tibet Railway. Cold Reg Sci Technol, 2005, 42: 169-176

19 Romanovsky V E, Smith S L, Christiansen H H. Permafrost thermal state in the Polar northern hemisphere during the International Polar Year 2007-2009: A synthesis. Permafrost Periglac Process, 2010, 21: $106-110$

20 Smith S L, Romanovsky V E, Lewkowicz A G, et al. State of permafrost in North America: A contribution to the International Polar Year. Permafrost Periglac Process, 2010, 21: 117-135

21 Romanovsky V E, Drozdov D S, Oberman N G, et al. Thermal state of permafrost in Russia. Permafrost Periglac Process, 2010, 21: 136-155

22 Zhao L, Wu Q B, Marchenko S S, et al. Thermal state of permafrost and active layer in central Asia during the International Polar Year. Permafrost Periglac Process, 2010, 21: 198-207

23 Christiansen H H, Etzelmuller B, Isaksen K, et al. The Thermal state of permafrost in the Nordic area during the International Polar Year 2007-2009. Permafrost Periglac Process, 2010, 21: 156-181

24 Cheng G D, Dramis F. Distribution of mountain permafrost and climate. Permafrost Periglac Processes, 1992, 3: 83-91

25 Cheng G D, Huang X M, Kang X C. Recent permafrost degradation along the Qinghai-Tibet Highway. In: Proceedings of 6th International Conference on Permafrost, Vol. 2, Guangzhou: South China University of Technology Press, 1993. 1010-1013

26 Wang S L. Permafrost change along Qinghai-Tibet Highway during ten years. Arid Land Geogr, 1993, 16: 1-7

27 Jin H, Li S, Cheng G, et al. Permafrost and climatic change in China. Glob Planet Change, 2000, 26: 387-404

28 Wang S L, Jin H J, Li S X, et al. Permafrost degradation on the Qinghai-Tibet Plateau and its environmental impacts. Permafrost Periglac Process, 2000, 11: 43-53

29 Wu Q, Liu Y. Ground temperature monitoring and its recent change in Qinghai-Tibet Plateau. Cold Reg Sci Technol, 2004, 38: 85-92

30 Zhao L. The Freezing-thawing processes of active layer and changes of seasonally frozen ground on the Tibetan Plateau. Dissertation for the Doctoral Degree. Lanzhou: Cold and Arid Regions Environmental and Engineering Research Institute, 2004

31 King L, Herz T, Hartmann H, et al. The PACE monitoring strategy: A concept for permafrost research in Qinghai-Tibet. Quat Int, 2006, 154-155: 149-157

32 Ding Y J, Ye B S, Liu S Y, et al. Monitoring of frozen soil hydrology in macro-scale in the Qinghai-Xizang Plateau. Chin Sci Bull, 2000, 45: 1143-1149
33 Yang M X, Yao T D, Gou X H, et al. The soil moisture distribution and melting-freezing processes and their effects on seasonal transition in Qinghai-Xizang (Tibet) Plateau. J Asian Earth Sci, 2003, 21: 456-464

34 Yang M X, Yao T D, Gou X H, et al. Diurnal freeze/thaw cycles of the ground surface on the Tibetan Plateau. Chin Sci Bull, 2007, 52: $136-139$

35 Li X, Cheng G D, Jin H J. Cryospheric change in China. Glob Planet Change, 2008, 62: 210-218

36 Yang M X, Nelson F E, Shiklomanov N I, et al. Permafrost degradation and its environmental effects on the Tibetan Plateau: A review of recent research. Earth Sci Rev, 2010, 103: 31-44

37 Wu Q B, Li X, Li W J. The prediction of permafrost change along the Qinghai-Tibet Highway, China. Permafrost Periglac Processes, 2000, 11: 371-376

38 Li X, Cheng G D, Wu Q B, et al. Modeling Chinese cryospheric change by using GIS technology. Cold Reg Sci Technol, 2003, 36: 1-9

39 Nan Z T, Li S X, Cheng G D. Prediction of permafrost distribution on the Qinghai-Tibet Plateau in the next 50 and 100 years. Sci China Ser D-Earth Sci, 2005, 48: 797-804

40 Pang Q Q, Cheng G D, Li S X, et al. Active layer thickness calculation over the Qinghai-Tibet Plateau. Cold Reg Sci Technol, 2009, 57: $23-28$

41 Zhang Z Q, Wu Q B. Freeze-thaw hazard zonation and climate change in Qinghai-Tibet Plateau permafrost. Nat Hazards, 2012, 61: 403-423

42 Wu T H, Li S X, Cheng G D, et al. Using ground-penetrating radar to detect permafrost degradation in the northern limit of permafrost on the Tibetan Plateau. Cold Reg Sci Technol, 2005, 41: 211-219

43 Jin $\mathrm{H} \mathrm{J}$, Zhao L, Wang S L, et al. Thermal regimes and degradation modes of permafrost along the Qinghai-Tibet Highway. Sci China Ser D-Earth Sci, 2006, 49: 1170-1183

44 Wu J C, Sheng Y, Wu Q B, et al. Processes and modes of permafrost degradation on the Qinghai-Tibet Plateau. Sci China Earth Sci, 2010, 53: $150-158$

45 Zhao L, Ping C L, Yang D, et al. Changes of climate and seasonally frozen ground over the past 30 years in Qinghai-Xizang (Tibetan) Plateau, China. Glob Planet Change, 2004, 43: 19-31

46 Zhao L, Liu G Y, Jiao K Q, et al. Variation of the permafrost in the Headwaters of the Urumqi River in the Tianshan Mountains since 1991. J Glaciol Geocryol, 2010, 32: 223-230

47 Jin H J, Wang S L, Lv L Z, et al. Features of permafrost degradation in Hinggan Mountains, Northeastern China. Sci Geogr Sin, 2009, 29: 223-228

48 Jin H J, Hao J Q, Chang X L, et al. Zonation and assessment of frozen-ground conditions for engineering geology along the ChinaRussia Crude Oil Pipeline route from Mo'he to Daqing, Northeastern China. Cold Reg Sci Technol, 2010, 64: 213-225

$49 \mathrm{Wu} \mathrm{Q}$, Zhang T. Changes in active layer change on the QinghaiTibetan Plateau from 1995-2007. J Geophys Res, 2010, 115: D09107

50 Wu Q B, Lu Z J, Liu Y Z. Permafrost change in the Tibet Plateau. Adv Clim Change Res, 2006, 2: 78-81

51 Brown J, Hemming J E. Workshop on environmental protection of permafrost terrain. Northern Engineer, 1980, 12: 30-36

52 Burgess M M, Smith S L. 17 years of thaw penetration and surface settlement observations in permafrost terrain along the Norman Wells pipeline, Northwest Territories, Canada. In: Herberli W, Brandova D, eds. Proceedings of the 8th International Conference on Permafrost, Zurich, Switzerland, 2003. 107-112

53 Smith S L, Burgess M M, Riseborough D W. Ground temperature and thaw settlement in frozen peatlands along the Norman Wells pipeline corridor, NWT Canada: 22 years of monitoring. In: Kane D L, Hinkel KM, eds. Proceedings of Ninth International Conference on Permafrost, Vol.2, Fairbanks Alaska, University of Alaska Fairbanks: Institute of Northern Engineering, 2008. 1665-1670

54 Smith S L, Nguyen T N, Riseborough D W, et al. Baseline geotech- 
nical and permafrost data from new field sites established in the Mackenzie corridor south of Norman Wells, Northwest Territories. Geol Surv Canada Current Res, 2010, 2: 15

55 Harris C, Arenson L U, Christianen $\mathrm{H} \mathrm{H}$, et al. Permafrost and climate in Europe: Monitoring and modeling thermal, geomorphological and geotechnical responses. Earth-Sci Rev, 2009, 92: 117-171

56 Wu Q B, Dong X F, Liu Y Z. Responses of permafrost on the Qinghai-Tibet Plateau to climate change and engineering action. Arct Antarct Alpine Res, 2007, 39: 682-687

57 Wu Q B, Liu Y Z, Yu H. Monitoring network of the permafrost conditions and embankment performance along the Qinghai-Tibet Railway. In: Kane D L, Hinkel K M, eds. Proceedings of Ninth International Conference on Permafrost, Vol.1, Fairbanks Alaska, University of Alaska Fairbanks: Institute of Northern Engineering, 2008, 1963-1968

58 Wu Q B, Liu Y Z, Zhang J M, et al. A Review of recent frozen soil engineering in permafrost regions along Qinghai-Tibet Highway, China. Permafrost Periglac Process, 2002, 13: 199-205

59 Wu Q B, Shi B, Liu Y Z. Study on interaction of permafrost and highway along Qinghai-Xizang Highway. Sci China Ser D-Earth Sci, 2003, 46: 97-105

60 Wu Q B, Shi B, Fan H Y. Engineering geological characteristics and processes of permafrost along the Qinghai-Xiang (Tibet) Highway. Eng Geol, 2003, 68: 387-396

61 Jin H J, Wei Z, Wang S L, et al. Assessment of frozen-ground conditions for engineering geology conditions along the Qinghai-Tibet highway and railway, China. Eng Geol, 2008, 101: 96-109

62 Wu Q B, Zhu Y L, Liu Y Z. Evaluating model of frozen soil environment change under engineering actions. Sci China Ser D-Earth Sci, 2002, 45: 893-902

63 Wu Q B, Zhu Y L, Liu Y Z. Evaluation Model of Permafrost Thermal stability and thermal thawing sensibility under Engineering Activity under Engineering Activity. Cold Reg Sci Technol, 2002, 34: 19-30

64 Sheng Y, Zhang J M, Liu Y Z, et al. Thermal regime in the embankment of Qinghai-Tibetan Highway in permafrost regions. Cold Reg Sci Technol, 2002, 35: 35-44

65 Liu Y Z, Wu Q B, Zhang J M. Deformation of highway roadbed in permafrost regions of the Tibetan Plateau. J Glaciol Geocryol, 2002, 24:10-15

66 Yu Q H, Liu Y Z, Tong C J. Analysis of the subgrade deformation of the Qinghai-Tibetan Highway. J Glaciol Geocryol, 2002, 24: 623-627

67 WANG S J, Chen J B, Zhang J Z, et al. Development of highway constructing technology in the permafrost region on the QinghaiTibet Plateau. Sci China Technol Sci, 2009, 52: 497-506

68 Wu Q B, Zhang Z Q, Liu Y Z. Long-term thermal effect of asphalt pavement on permafrost under embankment. Cold Reg Sci Technol. 2010, 60: 221-229

69 Cheng G D, Zhao L. The Problems associated with permafrost in the development of the Qinghai-Xizang Plateau. Quat Sci, 2000, 20: 521-531

70 Cheng G D. Construction of Qinghai-Tibet Railway with cooled roadbed. China Railway Sci, 2003, 24: 1-4

71 Ma W, Cheng G D, Wu Q B, et al. Application on idea of dynamic design in Qinghai-Tibet Railway construction. Cold Reg Sci Technol, 2005, 41: 165-173

72 Cheng $\mathrm{G} \mathrm{D}, \mathrm{Wu} \mathrm{Q} \mathrm{B}, \mathrm{Ma} \mathrm{W}$. Innovative designs of permafrost roadbed for the Qinghai-Tibet Railway. Sci China Technol Sci, 2009, 52: 530-538

73 Sun Y F. Permafrost Engineering in the Qinghai-Tibet Railway: Research and Practice. J Glaciol Geocryol, 2005, 27: 153-162

74 Sheng Y, Wen Z, Ma W, et al. Long-term evaluations of insulated road in the Qinghai-Tibetan Plateau. Cold Reg Sci Technol, 2006, 45: $23-30$

75 Wen Z, Sheng Y, Ma W, et al. In situ experimental study on thermal protection effects of the insulation method on warm permafrost. Cold Reg Sci Technol, 2008, 53: 369-381

76 Wen Z, Sheng Y, Ma W. Analysis on effect of permafrost protection by two-phase closed thermosyphon and insulation jointly. Cold Reg Sci Technol, 2005, 43: 150-163

77 Wen Z, Sheng Y, Ma W, et al. Analysis on the effect of Permafrost Protection by two-Phase closed joint thermosyphon and insulation in Permafrost regions. J Lanzhou Univ (Nat Sci), 2006, 42: 14-19

78 Smith L B, Graham J P, Nixon J F, et al. Thermal analysis of force-air and thermosyphon cooling system for the Inuvik airport expansion. Can Geothch J, 1991, 28: 399-409

79 John J, Zarling P. Thermosyphon application in cold regions. In: Proceedings of 4th International Symposium on Thermal Engineering \& Science for Cold Regions, CREERL, Special Report, 1993, 93-22: 24-38

80 Mckenna J K, Biggar K W. The rehabilitation of a passive-ventilated slab on grade foundation using horizontal thermosyphons. Can Geotech J, 1998, 35: 684-691

81 Wang S J, Chen J B, Huang X M. Numerical simulation of cooling effect for heat pipe subgrade. J Traff Transport Eng, 2005, 5: 41-46

82 Pan W D, Zhao S C, Xu W Z, et al. Application of thermal probe to enhance thermal stability of roadbeds in plateau permafrost areas. $\mathbf{J}$ Glaciol Geocryol, 2003, 25: 433-438

83 Li Y Q, Wu Z J, Wang Y S, et al. Test study on the application effect of the thermal pipes on the roadbed in the permafrost region along Qinghai-Tibet Railway. Chin Railway Sci, 2008, 29: 6-11

84 Guo H X, Wu Q B, Zhang L X. Applications and research of thermosyphon technology in cold regions. J Glaciol Geocryol, 2009, 31: 1137-1142

85 Niu F J, Cheng G D, Yu Q H. Ground-temperature controlling effects of duct-ventilated railway embankment in permafrost regions. Sci China Ser D: Earth Sci, 2004, 47: 152-160

86 Yu Q H, Cheng G D, Niu F J. The application of auto-temperaturecontrolled ventilation embankment in Qinghai-Tibet Railway. Sci China Ser D-Earth Sci, 2004, 47: 168-176

87 Lai Y M, Wang Q S, Niu F J. Three-dimensional nonlinear analysis for temperature characteristic of ventilated embankment in permafrost regions. Cold Reg Sci Technol, 2004, 38:165-184

88 Li G Y, Li N, Quan X J. The temperature features for different ventilated-duct embankments with adjustable shutters in the Qinghai-Tibet railway. Cold Reg Sci Technol, 2006, 44: 99-110

89 Lai Y M, Zhang L X, Zhang S J, et al. Cooling effect of ripped-stone embankments on Qinghai-Tibet railway under climatic warming. Chin Sci Bull, 2003, 48: 598-604

90 Zhang M Y, Lai Y M, Niu F J, et al. A numerical model of the coupled heat transfer for duct-ventilated embankment under wind action in cold regions and its application. Cold Reg Sci Technol, 2006, 45: 103-113

91 Zhang M Y, Lai Y M, Gao Z H, et al. Influence of boundary conditions on the cooling effect of crushed-rock embankment in permafrost regions of Qinghai-Tibetan Plateau. Cold Reg Sci Technol, 2005, 44: 225-239

92 Zhang M Y, Lai Y M, Li S Y, et al. Laboratory investigation on cooling effect of sloped crushed-rock revetment in permafrost regions. Cold Reg Sci Technol, 2006, 46: 27-35

93 Yu W B, Lai Y M, Sun Z Z, et al. Experimental studies on the ripped-rock revetment embankment in permafrost regions of the Qinghai-Tibet Railroad. Cold Reg Sci Technol, 2006, 45: 1-7

94 Feng W J, Ma W, Li D Q, et al. Application investigation of awning to roadway engineering on the Qinghai-Tibet Plateau. Cold Reg Sci Technol, 2006, 45: 51-58

95 Feng W J, Ma W, Wu Z J, et al. Application of awning to roadway engineering in permafrost regions. Chin J Geotech Eng, 2003, 25: 567-570

96 Yu Q H. Study on the heat conduction process of roadbed in permafrost regions and new control methods. Dissertation for the Doctoral Degree. Lanzhou: Cold and Arid Regions Environmental and Engineering Research Institute, 2006

97 Yu H, Wu Q B, Liu Y Z. The long-term monitoring system on permafrost regions along the Qinghai-Tibet Railway. J Glaciol Geocryol, 2008, 30: 475-481

98 Wu Q B, Lu Z J, Zhang T J, et al. Analysis of cooling effect of 
crushed rock-Based embankment of the Qinghai-Xizang Railway. Cold Reg Sci Technol, 2008, 53: 271-282

99 Ma W, Feng G L, Wu Q B, et al. Analyses of temperature fields under the embankment with crushed-rock structures along the QinghaiTibet Railway. Cold Reg Sci Technol, 2008, 53: 259-270

$100 \mathrm{Ma} \mathrm{W}, \mathrm{Mu}$ Y H, Wu Q B, et al. Characteristics and mechanisms of embankment deformation along the Qinghai-Tibet Railway in permafrost regions. Cold Reg Sci Technol, 2011, 67: 178-186

101 Mu Y H, Ma W, Wu Q B, et al. Thermal regime of conventional embankments along the Qinghai-Tibet Railway in permafrost regions. Cold Reg Sci Technol, 2012, 70: 123-131

$102 \mathrm{Mu} \mathrm{Y} \mathrm{H,} \mathrm{Ma} \mathrm{W,} \mathrm{Wu} \mathrm{Q} \mathrm{B,} \mathrm{et} \mathrm{al.} \mathrm{Cooling} \mathrm{processes} \mathrm{and} \mathrm{effects} \mathrm{of}$ crushed rock embankment along the Qinghai-Tibet Railway in permafrost regions. Cold Reg Sci Technol, 2012, 78: 107-114

103 Wu Q B, Li M Y, Liu Y Z. Thermal interaction of permafrost and the Qinghai-Tibet Railway. J Cold Reg Eng, 2010, 24: 112-125

104 Hu Z Y, Qian Z Y, Cheng G D, et al. Influence of solar radiation on embankment surface thermal regime of the Qinghai-Xizang Railway. J Glaciol Geocryol, 2002, 4: 121-128

105 Sheng Y, Ma W, Wen Z, et al. Analysis of difference in thermal state between south faced slope and north faced slope of railway embankment in permafrost regions. Chin J Rock Mechan Eng, 2005, 24: 3197-3201

106 Chou Y L, Sheng Y, Ma W. Study on the effect of the thermal regime differences in roadbed slopes on their thawing features in permafrost regions of Qinghai-Tibetan Plateau. Cold Reg Sci Technol, 2008, 53: 334-345

107 Chou Y L, Sheng Y, Wei Z M, et al. Calculation of temperature differences between the sunny slopes and the shady slopes along railways in permafrost regions on Qinghai-Tibet Plateau. Cold Reg Sci Technol, 2008, 53: 346-354

108 Chou Y L, Sheng Y, Zhu Y P. Study on the relationship between the shallow ground temperature of embankment and solar radiation in permafrost regions on Qinghai-Tibet Plateau. Cold Reg Sci Technol, 2012, 78: 122-130

109 Zhang M Y, Lai Y M, Liu Z Q, et al. Nonlinear analysis for the cooling effect of Qinghai-Tibetan railway embankment with different structures in permafrost regions. Cold Reg Sci Technol, 2005, 42: 237-249

110 Wu Q B, Liu Y Z, Hu Z Y. The thermal effect of differential solar exposure on embankments along the Qinghai-Tibet Railway. Cold Reg Sci Technol, 2011, 66: 30-38

111 Harris S A, Pedersen D E. Thermal regimes beneath coarse blocky materials. Permafrost Periglac Process, 1998, 9: 107-120

112 Gorbunov A P, Marchenko S S, Seversky E V. The Thermal envi- ronment of blocky materials in the mountains of central Asia. Permafrost Periglac Process, 2004, 15: 95-98

113 Cheng G D. Influences of local factors on permafrost occurrence and their implications for Qinghai-Tibet Railway design. Sci China Ser D-Earth Sci, 2004, 47: 704-709

114 Harris S A. Lower mean annual ground temperature beneath a block stream in the Kunlun Pass, Qinghai Province, China. In: Proceedings fifth Chinese conference on Glaciololgy and Geocryology. Lanzhou: Science Press, 1996. 227-237

115 Cheng G D, Tong B L, Luo X B. Two important problems of embankment construction in the section of massive ground ice. J Glaciol Geocryol, 1981, 3: 6-11

116 Cheng G D, Tong B L. Experimental research on an area with massive ground ice at the lower Limit of alpine permafrost. In: Proceedings of the 3rd International Conference on Permafrost, Vol 2, Natural Research Council of Canada, 1978, 199-222

117 Wang G S, Lin Q, Jin H J. Experimental study on the quarried rock ventilated embankment in cold regions. In: Proceeding of the Fifth Chinese Conference on Glaciololgy and Geocryology, Vol. 1, Lanzhou: Gansu Culture Press, 1996. 377-382

118 Goering D J, Kumar P. Permeability Effects on winter-time natural convection in gravel embankments. Adv Cold Regions Thermal Engineer Sci, 1999, 455-464

119 Goering, D J. Passively cooled railway embankments for use in permafrost Areas. J Cold Regions Eng, 2003, 17: 119-133

120 Jiang F, Liu S, Wang $\mathrm{H}$. The air flow and heat transfer in gravel embankment in permafrost areas. Sci China Ser D-Earth Sci, 2004, 47 : $142-151$

121 Wu Q B, Cheng H B, Jiang G L, et al. Cooling mechanism of embankment with block stone interlayer in Qinghai-Tibet railway. Sci China Ser E: Technol Sci, 2007, 50: 319-328

122 Wu Q B, Li M Y, Liu Y Z. Cool effect of crushed rock structure on permafrost under embankment. Sci Cold Arid Reg, 2009, 1: 39-50

123 Wu Q B, Liu G, Zhang T J, et al. In-situ experimental study of heat transfer process within crushed rock layer along the Qinghai-Tibet Railway. Int J Offshore Polar Eng, 2010, 20: 1-8

124 He P, Zhang Z, Cheng G D, et al. Ventilation properties of blocky stones embankments. Cold Reg Sci Technol, 2007, 47: 271-275

125 Cheng G D, Lai Y M, Sun Z Z, et al. The "thermal semi-conductor" effect of crushed rocks. Permafrost Periglac Process, 2007, 18: $151-160$

$126 \mathrm{Wu} \mathrm{Q}$ B, Yu H, Jiang G L, et al. Analysis of temperature features within crushed rock revetment and cooling mechanism of embankments for the Qinghai-Tibet Railway. Chin J Geotechnol Eng, 2008, 30: $1011-1016$

Open Access This article is distributed under the terms of the Creative Commons Attribution License which permits any use, distribution, and reproduction in any medium, provided the original author(s) and source are credited. 